\title{
Identification of QTLs Associated with Nitrogen Use Efficiency and Related Traits in a Diploid Potato Population
}

\author{
Baye Berihun Getahun ${ }^{1,2}$ (D) $\cdot$ Richard G. F. Visser ${ }^{1} \cdot$ C. Gerard van der Linden ${ }^{1}$
}

Published online: 3 March 2020

(C) The Author(s) 2020

\begin{abstract}
Developing $\mathrm{N}$ use efficient potato varieties requires exploring the genetic basis of nitrogen use efficiency (NUE) and associated agronomic and physiological traits. In order to identify QTLs for NUE and NUE-related traits, and to determine the relationships between the traits and QTLs in potato, a diploid potato mapping population $(\mathrm{CxE})$ was evaluated in the field in Ethiopia under low and high $\mathrm{N}$ fertilizer levels. QTL detection was performed using interval mapping and multiple QTL mapping (MQM). A total of 52 putative QTLs were identified for ten traits, of which 28 QTLs were detected under low N availability while the remaining 24 QTLs were detected under high N conditions. Several QTLs were location and N level specific, suggesting the presence of QTL $\mathrm{x}$ environment interaction. A region on linkage group $\mathrm{V}(21-38 \mathrm{cM})$ accumulated the largest number of QTLs. This region coincides with the earliness locus encoded by the CDF1 gene, suggesting that earliness has a profound influence on NUE. A putative second QTL region on linkage group V located $20 \mathrm{cM}$ from the earliness locus $(38-56 \mathrm{cM})$ and a region on linkage group IV $(60-72 \mathrm{cM})$ might be useful other regions to focus on, for NUE improvement in potato. To verify the stability of the identified QTLs and to use these for the detection of possible candidate genes, further multi-environment trials with larger population size may be required.
\end{abstract}

\section{Resumen}

El desarrollo de variedades de papa eficientes en el uso del $\mathrm{N}$ requiere de la exploración de las bases genéticas en la eficiencia del uso del nitrógeno (NUE) asociadas a caracteres agronómicos y fisiológicos. A fin de identificar QTLs para NUE y para rasgos relacionados con NUE, y para determinar las relaciones entre los caracteres y QTLs en papa, se evaluó un mapa de población de papa diploide (CxE) en el campo en Etiopia en niveles bajos y altos de fertilizante nitrogenado. La detección de QTL se efectuó usando mapeado a intervalos y mapeo múltiple de QTL (MQM). Se identificaron un total de 52 posibles QTL para diez rasgos, de los cuales 28 QTL se detectaron en baja disponibilidad de $\mathrm{N}$, mientras que los restantes 24 se detectaron en altas condiciones de N. Varios QTL fueron específicos para localidad y nivel de N, sugiriendo la presencia de la interacción QTL x ambiente. Una región de agrupamiento ligado V (21-38 cM) acumuló el mayor número de QTLs. Esta región coincide con el locus de precocidad codificado por el gen CDF1, lo que sugiere que la precocidad tiene una influencia profunda en NUE. Una supuesta segunda región QTL en el grupo de ligamiento V localizado a $20 \mathrm{cM}$ del locus de precocidad $(38-56 \mathrm{cM})$ y una región del grupo de ligamiento IV $(60-72 \mathrm{cM})$ pudiera ser útil para enfocarse en otras regiones, para mejoramiento de NUE en papa. Para verificar la estabilidad de los QTL identificados y para usarlos en la detección de posibles genes candidatos, se pudieran requerir ensayos multiambiente posteriores con tamaños mas grandes de población.

Keywords Diploid potato $\cdot$ Nitrogen use efficiency $\cdot$ Quantitative trait loci $\cdot$ Nitrogen

Electronic supplementary material The online version of this article (https://doi.org/10.1007/s12230-020-09766-4) contains supplementary material, which is available to authorized users.

Baye Berihun Getahun

baye.bgetahun@gmail.com

1 Plant Breeding, Wageningen University and Research, P.O. Box 386, 6700, AJ Wageningen, The Netherlands

2 Amhara Regional Agricultural Research Institute, ARARI, P.O. Box. 527, Bahirdar, Ethiopia

\section{Introduction}

Crop productivity is greatly affected by nutrient availability and nutrient use efficiency. Nitrogen Use Efficiency (NUE) has become the second priority production constraint after drought in crop abiotic stress improvement programs (Hirel et al. 2011). Indeed, improving agronomic NUE is relevant for the majority of crops currently cultivated. Less than $50 \%$ of the applied nitrogen is typically used by most crops and a large amount of $\mathrm{N}$ fertilizer is required to reach maximum yield 
(Zhang et al. 2007). The $\mathrm{N}$ that is not utilized by the plant is lost due to nitrate leaching, denitrification and loss of ammonia to the atmosphere which has a harmful effect on the environment as well as on the economy (Glass 2003).

$\mathrm{N}$ availability affects many developmental processes, depending on the plant species (Zheng 2009). In potato, $\mathrm{N}$ availability affects rate of canopy development and leaf appearance, final leaf size, rate of photosynthesis, onset of tuberization, final tuber yield and harvest index (Vos and Biemond 1992; Ewing and Struik 1992; Vos 1995; Vos and Mackerron 2000; Ospina et al. 2014). Deficiencies or variation in availability of nitrogen and other soluble nutrients cause poor vegetative growth and health, reduced pathogen and insect resistance, decreased tuber yields, and these affect tuber quality as well (Ojala et al. 1990; Olsen et al. 2003; Stark et al. 2004). In general, potato requires high amounts of $\mathrm{N}$ fertilizer to give maximum tuber yield, however the crop is relatively poor in agronomic NUE (yield produced per nitrogen applied). The high nitrogen requirement and low use efficiency is not only because of low $\mathrm{N}$ utilization by the plant, but also because of inefficient uptake due to its shallow inefficient root system (Munoz et al. 2005; Pack et al. 2006). Nitrogen use efficiency (NUE) is typically calculated as the yield per unit of $\mathrm{N}$ resource available to the plant (Moll et al. 1982). However, the method of NUE determination depends on the crop species and the objective of the study. In our case NUE was determined as the tuber dry matter production, or dry weight of the tuber, per unit of $\mathrm{N}$ supplied (agronomic NUE).

In potato, a wide range of variation in NUE has been reported in cultivated potato clonal selections, and accessions of wild potato species (Errebhi et al. 1998, 1999; Zebarth et al. 2004; Zvomuya et al. 2002; Sharifi et al. 2007), suggesting the possibility of improving NUE through breeding. Various traits related to NUE and contributing to NUE were used to increase the efficiency of the selection process and support the development of cultivars that give reasonable yield under low $\mathrm{N}$ availability (Errebhi et al. 1998). Among these traits, nitrogen uptake efficiency, yield and its components, Leaf Area Index (LAI) and period for maximum soil covering showed significant variation at low $\mathrm{N}$ conditions (Tiemens-Hulscher et al. 2012). However, the genetic basis of NUE is still poorly understood, and the complexity of many phenotypic traits involved in adaptation to stress conditions is likely to arise from a number of quantitative trait loci (QTL) (Bulmer 1985; Falconer and Mackay 1996). To dissect the complexity of such quantitative traits into component loci and identify the genetic factors that influence quantitative traits, QTL analysis via genetic mapping is a powerful tool (Doerge 2002). For instance, a QTL approach offers the opportunity to dissect physiological and genetic components that affect the sourcesink relationship under abiotic stress conditions (Pelleschi et al. 2006; Welcker et al. 2007; Miralles and Slafer 2007), which is likely to be a major component for potato yield.
QTL analysis also provides opportunities for the analysis of the relationships between traits (Lebreton et al. 1995; Simko et al. 1997). Co-localization of QTLs for two traits that are phenotypically correlated is good evidence that the two traits might be functionally and genetically linked (Quarrie 1996; Thumma et al. 2001). Simko et al. (1997) used QTL analysis to evaluate the causal relationship between tuber dormancy and abscisic acid (ABA) content. In maize, the relationship between $\mathrm{ABA}$ as a major stress hormone with yield and other drought related traits was analysed using a QTL approach (Lebreton et al. 1995; Quarrie 1996). However, QTLs can be affected by environmental variation. Some QTLs exist consistently over environments (constitutive QTLs), while other QTL are identified only in specific environments, or modulate their effect with changing environmental conditions (adaptive QTLs) (Tuberosa et al. 2008). Studies of QTLs affecting traits related to NUE have been reported in maize (Agrama et al. 1999; Hirel and Lea 2001; Hirel et al. 2011), Arabidopsis (Loudet et al. 2003) and rice (Cho et al. 2007), and many of these QTLs were dependent on $\mathrm{N}$ levels.

In the last two decades many QTL analysis studies have been published on different traits of potato, such as flower colour, foliage maturity, tuber skin texture, dry matter content, specific gravity and yield (McCord et al. 2011), yield, agronomic and quality traits (Bradshaw et al. 2008), tuber yield and starch content (Schafer-Pregl et al. 1998), tuber dormancy (van den Berg et al. 1996), tuber shape (Van Eck et al. 1994), tuber skin colour (Gebhardt et al. 1989), tuber flesh colour (Bonierbale et al. 1988) and drought related traits (Anithakumari et al. 2011, 2012; Khan et al. 2014). The number of QTL studies for NUE are still very limited. Only recently QTLs affecting traits related to NUE under contrasting $\mathrm{N}$ regimes were reported in potato (Ospina 2016). The aims of the present study were: (1) To determine the chromosomal location and genetic effect of QTLs for NUE and traits associated with NUE in potato under low and high $\mathrm{N}$ conditions in Ethiopia, and (2) Deliver basic genetic and physiological information of NUE and related traits for future candidate gene identification and marker assisted selection studies.

\section{Materials and Methods}

\section{Plant Materials}

One hundred individuals of a diploid backcross population $(\mathrm{CxE})$ including the parents were used in this study. The population was obtained from the original cross between the female parent, C (USW5337.3) (Hanneman and Peloquin 1967) and the male parent, E (77.2102.37) (Jacobsen 1980). Clone C is a hybrid of $S$. phureja (PI225696.1) and S. tuberosum dihaploid USW42. Clone $\mathrm{E}$ is the result of a cross between clone $\mathrm{C}$ and the $S$. vernei-S. tuberosum backcross clone 
VH34211 (Jacobsen 1980). Absence of dormancy, early maturity and short day tuberization are some of the characteristics of S. phureja. On the contrary, Solanum tuberosum is characterized by long dormancy, long day tuberization and variable maturity (Hawkes 1990; Ewing and Struik 1992).

\section{Field Studies}

The field studies were conducted in Ethiopia at Koga from January to May 2014 and at Injibara and Debre-Tabor from July to October 2014 under irrigation and rainfed conditions, respectively. In Ethiopia, the rainfed production season is from June to October, and is fully dependent on rain water. The irrigation production season is from Nov-April and is fully dependent on irrigation water from rivers and streams. The experiment was laid out in a split plot arrangement with two replications, with low and high $\mathrm{N}$ levels $(40 \mathrm{~kg} / \mathrm{ha}$ and $120 \mathrm{~kg} / \mathrm{ha}$ ) assigned as main plots and the genotypes as sub plots. Each replication consisted of 10 plants, planted at a recommended inter- and intra-row spacing of $0.75 \mathrm{~m}$ and $0.30 \mathrm{~m}$ respectively and each genotype replication was bordered by a plant from reference cultivar. Soil available nutrients and externally applied urea, Di-ammonium phosphate (DAP) and tri-superphosphate (TSP) were used as source of $\mathrm{N}$ and $\mathrm{P}$. Composite soil samples were collected at five different locations in the experimental field and at a soil depths of 0$20 \mathrm{~cm}$ and $20-40 \mathrm{~cm}$ before planting to estimate the available residual nitrogen in the form of $\mathrm{NO}_{3}{ }^{-}$and $\mathrm{NH}_{4}{ }^{+}$using a $\mathrm{KCl}$ extraction method. The whole $\mathrm{P}$ source was applied at planting while $\mathrm{N}$ application was split in two: a week after emergence and at early flowering. Pest and disease management, weeding and ridging and other cultivation practices were conducted as per recommendation and when required.

\section{Phenotypic Measurements}

The phenotypic measurements were carried out in similar manner at all experimental locations (Koga, Debre-Tabor and Injibara). Plant height (PH), Chlorophyll content (CC) at lower and upper part leaf using SPAD-502 chlorophyll meter (Minolta Co., Ltd. Japan) were measured when $50 \%$ of the genotypes were flowering. The readings for chlorophyll content were taken on the third or fourth leaf from the top of the plant for upper leaf chlorophyll content (UCC), and the second or the third leaf from the base of the plant for lower leaf chlorophyll content (LCC). Stem number per plant (SNPP) was counted before the plant foliage declined. Canopy cover dynamics or soil cover (SC) was assessed every five days starting from date of full emergence to the declining phase of the crop growth using a $0.6 \mathrm{~m} \times 0.75 \mathrm{~m}$ frame with 100 grid squares, positioned over the same middle plants in a plot for each measurement, and the canopy measurements were carried out from date of full emergence (41 days after planting) to the end of the declining phase of the crop growth. The beta thermal time for canopy cover assessment was calculated from the date of emergence for each experimental unit, using the sigmoid part of the beta function for determinate growth (Yin et al. 2003), and an estimated cardinal temperature $\left(5.5^{\circ} \mathrm{C}\right.$ as a base temperature, $23.37{ }^{\circ} \mathrm{C}$ as optimum, and $34.58^{\circ} \mathrm{C}$ as ceiling temperature that determines the vegetative growth of potato (Khan 2012; Khan et al. 2013). Hourly temperature data was collected from the nearest weather station for each location. The model for canopy development was fitted using the soil cover data, beta thermal time for each assessment, and the canopy cover measurements, and the following model parameters were estimated: the inflection point in the build-up phase of the growth curve (tm1), time at which canopy cover reaches its maximum (t1), the maximum canopy cover value with percentage of soil cover as unit (Vmax), time for onset of canopy decline ( $\mathrm{t} 2$ ), time when canopy cover reaches zero (te), and area under the curve for the entire crop growth cycle (AUC) in \%.thermal day $(\mathrm{td})$, were estimated using the NOLIN procedure of SAS, SAS Institute Inc., 2004 (Khan et al. 2013). Days to maturity (DTM), determined as the number of the days from emergence to the day at which more than $90 \%$ of the plants in a plot attained physiological maturity $(90 \%$ of the haulm tissues brown) was assessed every day starting from the time that early varieties showed the first signs of leaf yellowing.

Tuber traits: tuber number per plant (TNPP), average tuber weight (ATW), tuber yield per plant (TYPP), Specific gravity (SG), tuber dry matter percentage (TDM\%) and Nitrogen Use Efficiency (NUE; defined as dry tuber weight per unit $\mathrm{N}$ available ( $\mathrm{N}$ applied $+\mathrm{N}$ available in the soil) were measured and estimated at harvest. Specific gravity (SG) was determined using the tuber specific gravity procedure of weight in air and under water (Murphy and Goven 1959). In evaluating the SG of each variety, healthy and marketable-sized grade $(20 \mathrm{~mm}$ and above) tubers were selected randomly from each variety harvest. Then, tubers were cleaned, and weighed both in air and water following the procedure of Murphy and Goven (1959). Specific gravity values were computed using the following formula:

$S G=\frac{W_{1}}{W_{1}-W_{2}}$

where $\mathrm{SG}=$ specific gravity of the material, $\mathrm{W}_{1}=$ weight in air of the sample tuber, in $g$ and $\mathrm{W}_{2}=$ Weight of the sample completely immersed in water, in g. Tuber dry matter content (TDM\%) normally is determined as a ratio of dry tuber weight to fresh weight expressed in percentage; we determined TDM\% indirectly from SG using empirical conversion factors following the equation of Kleinkopf et al. (1987): solid (Dry matter \%) $=-214.9206+(218.1852 \times$ SG). Tuber dry weight $($ TDW $)$ was estimated indirectly from specific gravity and tuber dry matter content in percent, using the following formula: 

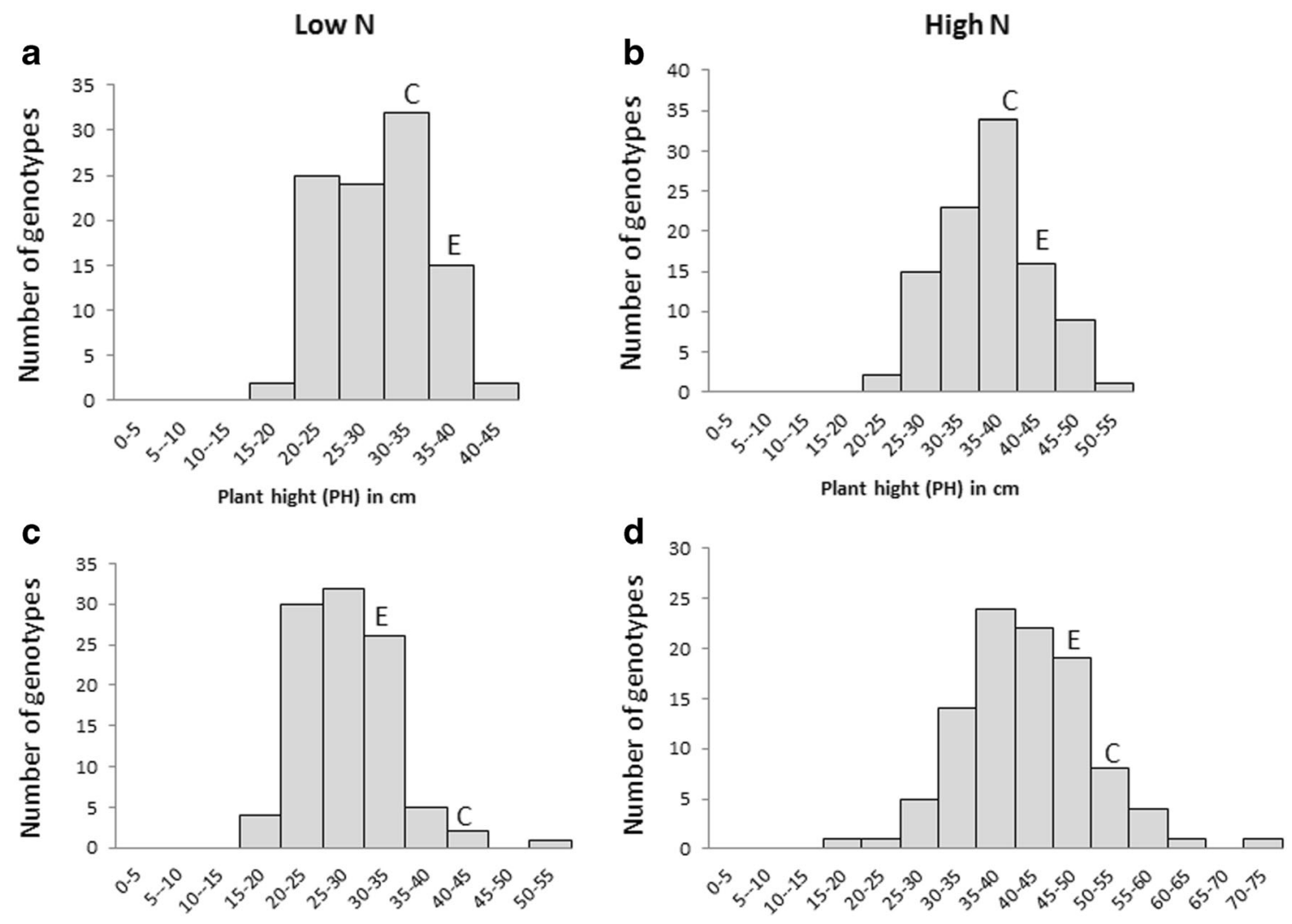

Maximum canopy cover (Vmax) in \%
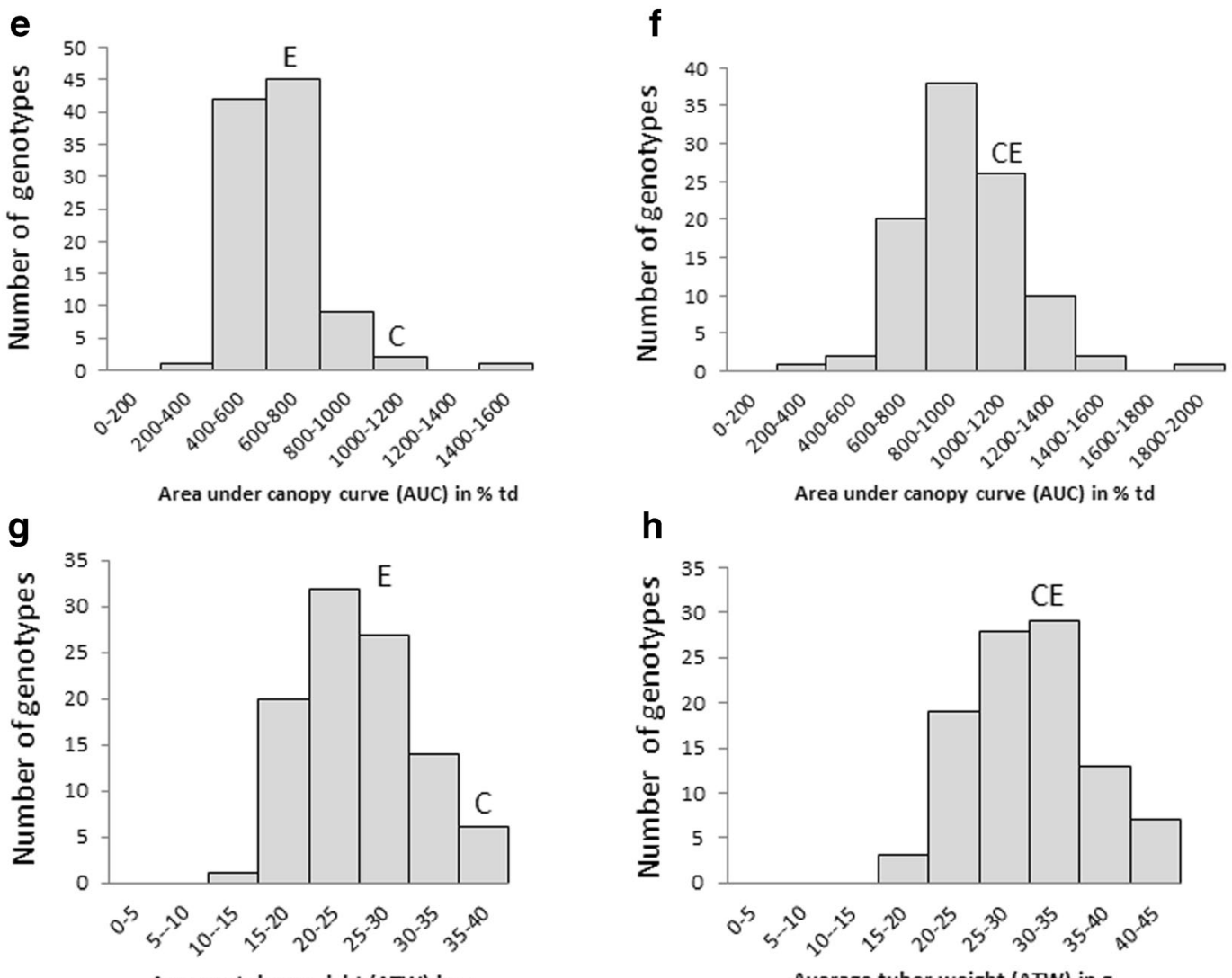

h

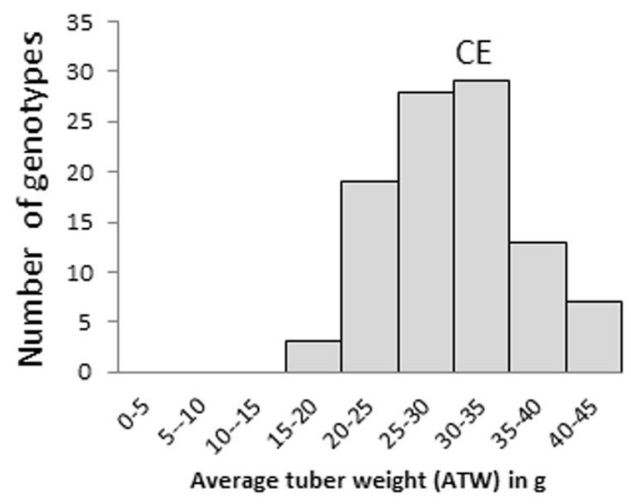


Fig. 1 Effect of $\mathrm{N}$ levels on the phenotypic distributions of some selected traits for parent $\mathrm{C}, \mathrm{E}$ and the $\mathrm{C} \mathrm{xE}$ potato genotypes. $\mathrm{PH}=$ plant height, $\mathrm{Vmax}=$ maximum canopy cover, $\mathrm{AUC}=$ area under the canopy curve, $\mathrm{ATW}=$ average tuber weight, TYPP $=$ tuber yield per plant. a) plant height at low $\mathrm{N}, \mathrm{b}$ ) plant height at high $\mathrm{N}, \mathrm{c}$ ) maximum canopy cover at low $\mathrm{N}$, d) maximum canopy cover at high $\mathrm{N}$, e) area under the canopy curve at low $\mathrm{N}, \mathrm{f}$ ) area under the canopy curve at high $\mathrm{N}, \mathrm{g}$ ) average tuber weight at low $\mathrm{N}, \mathrm{h}$ ) average tuber weight at high $\mathrm{N}$, i) tuber yield per plant at low $\mathrm{N}, \mathrm{j}$ ) tuber yield per plant at high $\mathrm{N}$

$$
D W t=\frac{T D M * F W t}{100}
$$

Where DWt $=$ dry weight of the tuber in $\mathrm{g}, \mathrm{TDM}=$ Tuber dry matter $(\%), \mathrm{FWt}=$ fresh weight of the tuber in $\mathrm{g}$. Nitrogen use efficiency (NUE) is calculated as the yield per unit of $\mathrm{N}$ resource available to the plant (Moll et al. 1982). In this study, NUE was determined as the tuber dry matter production, or dry weight of the tubers/ha, per unit of $\mathrm{N}$ supplied/ha $(\mathrm{N}$ in the soil + applied N).

\section{Statistical Analyses}

Analyses of variance (ANOVA) of the different traits, correlation and principal component analysis (PCA) were done with GenStat software 17th edition. Restricted maximum likelihood (REML) variance component analysis, genotypic variance $\left(\sigma^{2} \mathrm{~g}\right)$, environmental variance $\left(\sigma^{2} \mathrm{e}\right)$ and broad sense heritability $\left(\mathrm{H}^{2}\right)$ were estimated using Breeding View, the IBP Breeding Management system (BMS) version 3.0.9 (https://www.integratedbreeding.net/breeding-managementsystem), with a model broad sense heritability $\left(\mathrm{H}^{2}\right)=\sigma^{2} \mathrm{~g} /$ $\left(\sigma^{2} \mathrm{~g}+\sigma^{2} \mathrm{e} / \mathrm{r}\right)$, where $\left(\sigma^{2} \mathrm{~g}\right)$ is the genotypic variance, $\left(\sigma^{2} \mathrm{e}\right)$ is the environmental variance and $r$ is the number of replications. To generate phenotypic values for QTL mapping, the genotype was modelled as a fixed effect and all other effects were random, and the best linear unbiased estimates (BLUE) means were computed with BMS-breeding view software.

\section{Genetic Map Construction}

Details of the genetic map and markers employed like Simple Sequence Repeats (SSR), Amplified Fragment Length Polymorphism (AFLP), Cleavage Amplified Polymorphism (CAP) and Single Nucleotide Polymorphism (SNPs) can be found in Anithakumari et al. (2011). The integrated CE map constructed using JoinMap 4.0 (Kyazma, Van Ooijen 2006) was utilized for the QTL analysis.

\section{QTL Analyses}

MapQTL6 (Kyazma, Van Ooijen 2009) was used for the QTL analysis. Each trait was analysed using interval mapping. For this analysis, a map with 12 linkage groups and 534 SNP and other markers with a total genetic map distance of $1326 \mathrm{cM}$ were employed, equivalent to an average distance between markers of $2.5 \mathrm{cM}$ assuming that these are equally distributed. Significance for QTL detection was determined by permutation tests (1000 permutations) and a genome wide scan was used as a QTL detection threshold at 5\% significant level. Subsequently, Multiple QTL Mapping (MQM) was performed with the markers nearest to the QTLs detected by interval mapping selected as cofactors.

\section{Results}

\section{Phenotypic Variation, Heritability and Variance Components}

The $\mathrm{C} \times \mathrm{E}$ diploid potato backcross population was grown at three different locations in two different production seasons (rainfed and irrigation) under low and high $\mathrm{N}$ fertilizer regimes to evaluate potato genotypes for NUE. NUE is defined in different ways, depending on the objective of the study and the crop under study (Good et al. 2004). In this study NUE is defined as the dry tuber yield per unit of nitrogen resource available to the plant. The combined analysis of variance over location showed that the genotypic variation was highly significant for all of the traits measured (supplementary Table 1), indicating that sufficient variation is present in the population for genetic analysis. In addition to the genotype, significant effects were observed for location, the interaction of location with $\mathrm{N}$ levels and genotype $\mathrm{x}$ location interaction for most agronomic and physiological traits. These results indicate that the genotype $\mathrm{x}$ location interaction often had a larger effect than the genotype $\mathrm{x} \mathrm{N}$ level interaction, suggesting that genotype $\mathrm{x}$ location interaction contributed more to the total genotype $\mathrm{x}$ environment interaction.

Mean values of different yield and yield related traits of the parents $\mathrm{C}$ and $\mathrm{E}$, minimum and maximum performance of progeny and genetic variance components under low and high nitrogen condition across locations are presented in supplementary Table 2 . The two parents $(\mathrm{C}$ and $\mathrm{E})$ performed differently in tuber yield and foliage traits (canopy cover parameters) under both $\mathrm{N}$ conditions. Parameters describing different aspects of canopy growth and development were derived from the canopy cover dynamics of potato as quantified by the grid method, and modelled using beta thermal time as described in the material and methods section (Khan et al. 2013). Among the canopy cover parameters, the maximum value of the canopy cover (Vmax), and the total area under the canopy (AUC), which reflects the capacity of the crop to intercept solar radiation during the whole growing period were the predominant traits that were considerably different between the two parents. Parent $\mathrm{C}$ showed higher mean performance compared to parent $\mathrm{E}$ in tuber yield related traits as well as foliage traits under low and high $\mathrm{N}$ conditions in all locations except for 

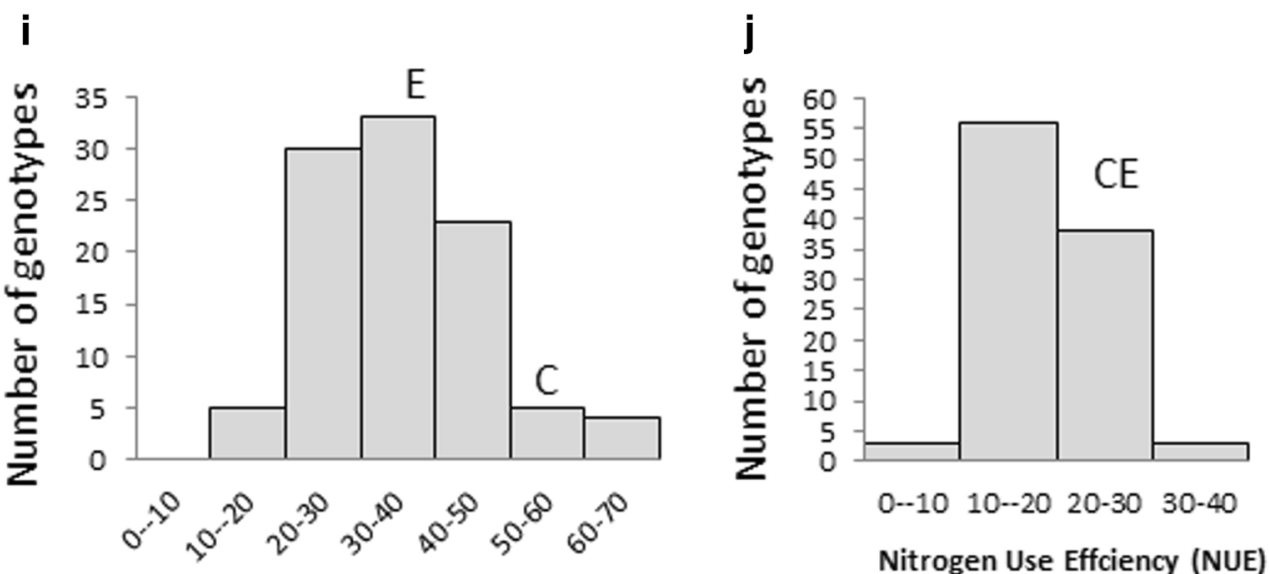

Nitrogen Use Effciency (NUE)
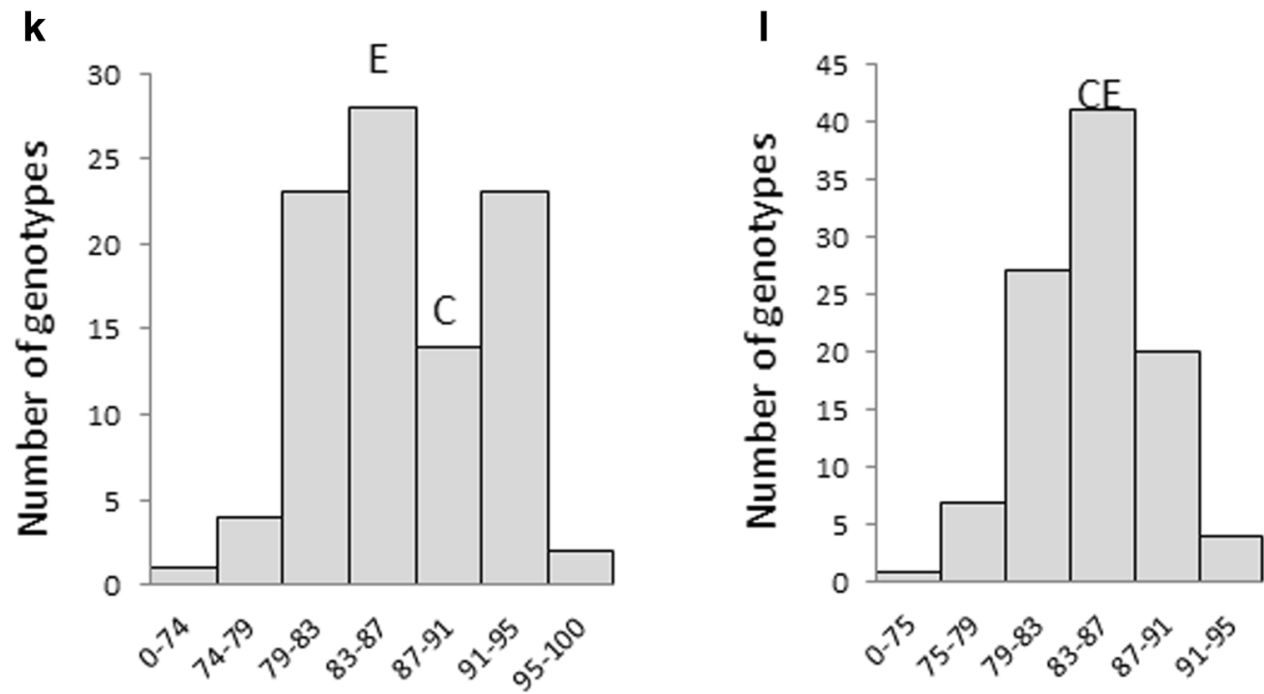

Days to maturity (DTM)

Days to Matuirty (DTM)

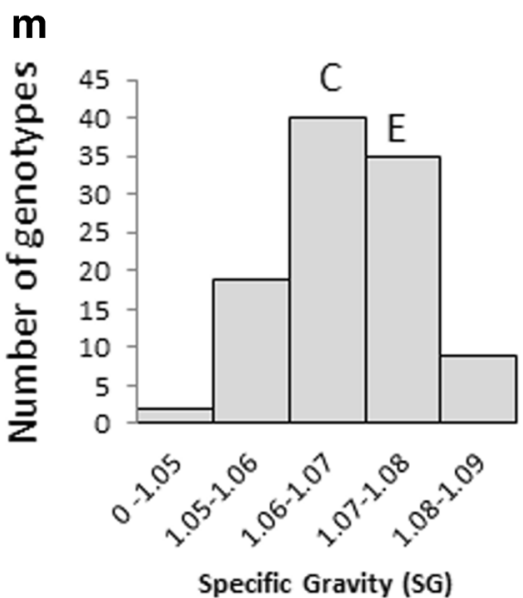

Fig. 1 (continued)

maximum canopy cover (Vmax) and total area under the canopy cover (AUC) at Debre-Tabor, for which parent E performed better than parent $\mathrm{C}$. The mean performance of the parents for most of the traits was a bit higher than the mean of the progeny (Figure 1).

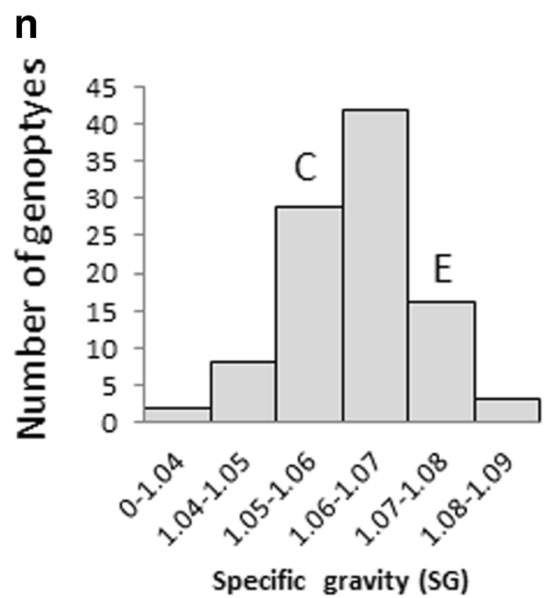

The effect of $\mathrm{N}$ levels was significant (according to a student's T test) for most agronomic and physiological NUE related traits considered in this study. Significant phenotypic variation $(P \leq 0.001)$ was observed for $\mathrm{N}$ level in the CE population and between the two parents for most traits measured 
in this study except stem number per plant (SNPP), the inflection point in the build-up phase of the growth curve $(\operatorname{tm} 1)$, time for onset of canopy decline $\left(\mathrm{t}_{2}\right)$, and time when canopy is completely senesced (te). Low N application substantially affected agronomic and physiological traits of the parents, with stronger performance reductions for parent $\mathrm{E}$ than for parent $C$. The overall differences for selected traits between parent $\mathrm{C}$ and parent $\mathrm{E}$, and the progeny are presented in Table 1.

Significant differences $(P \leq 0.05)$ in days to maturity (DTM) were found due to the effect of $\mathrm{N}$ levels, and of genotype. The genotypes matured on average between 75 and 95 days at both $\mathrm{N}$ levels. Based on the total number of days to reach maturity, genotypes were grouped as early (between 75 and 82 days), intermediate (between 83 and 89 days) and late maturing ones ( 90 days and above). Large differences were found between late and early maturing genotypes for Vmax, AUC, TYPP, and NUE at the same N level. Late maturing cultivars showed higher canopy cover compared to early ones under low $\mathrm{N}$ conditions (see example for some genotypes in Fig. 2).

The heritability of the traits varied from 0 to 0.83 under low $\mathrm{N}$ and from 0.37 to 0.86 under high $\mathrm{N}$ conditions (supplementary Table 2). For most traits, the highest heritability was recorded at high $\mathrm{N}$ level compared to low N. However, the heritability estimate difference between high and low $\mathrm{N}$ conditions was negligible. The highest heritability value difference $(0.43)$ between high and low $\mathrm{N}$ conditions was observed for the trait AUC followed by LCC (0.40) at DebreTabor and Injibara respectively. Among the locations, Koga showed higher heritability estimates for most traits compared to Debre-Tabor and Injibara. Except tuber dry matter and chlorophyll content, for most traits the genotypic variance value is higher than that of environmental variance (supplementary Table 2), indicating that the contribution of the genetic factor to the total phenotypic variation was large compared to the environmental factor.

\section{Correlation and Principal Component Analysis (PCA)}

The phenotypic correlation coefficients of traits under low and high $\mathrm{N}$ condition are presented in Table 2. The correlation between NUE and most agronomic and physiological traits was positive and significant both under low and high $\mathrm{N}$ conditions. However, depending on the traits, some differences in correlations were observed between low and high $\mathrm{N}$ levels. LCC and UCC are traits that correlate negatively with most traits at both $\mathrm{N}$ levels.

The two tuber yield component traits (TNPP and ATW) were significantly negatively correlated under low and high $\mathrm{N}$ conditions ( -0.36 and -0.37 respectively), which reflects a trade-off between the two traits both under low and high $\mathrm{N}$ availability.
Principal component analysis (PCA) is one of the main statistical tools widely used to categorise phenotypic traits into groups based on similarities. The principal component analysis biplots in Figs. 3 and 4 depict the distribution and similarities of $100 \mathrm{CE}$ potato progeny genotypes including their parents under low (Fig. 3) and high N conditions (Fig. 4) over all locations combined. In the PCA $52.81 \%$ and $53.87 \%$ of the total variance was explained by $\mathrm{PC} 1$ and $\mathrm{PC} 2$ together under low and high $\mathrm{N}$ conditions, respectively. The angles between vectors in the biplot indicate the level of association between traits. An angle less than $90^{\circ}$ (acute angle) suggests presence of strong positive correlation, an angle greater than $90^{\circ}$ (obtuse angle) suggests a weak correlation. Thus, the biplots point out the genetic relationship between traits. As shown in the biplots a strong correlation was observed between tuber number per plant (TNPP) and days to maturity (DTM); and NUE and tuber yield per plant (TYPP) under low $\mathrm{N}$ condition. Under high $\mathrm{N}$ there was strong correlation between average tuber weight (ATW), plant height ( $\mathrm{PH})$, and days to maturity (DTM); between maximum canopy cover (Vmax), Tuber yield per plant (TYPP), tuber number per plant (TNPP) and time at which canopy cover reaches its maximum (t1).

\section{QTL Detection}

The QTL analysis was done separately for each $\mathrm{N}$ level at each location. We have done QTL analysis for all measured traits, and we found QTL for ten traits at three experimental locations (Debre-Tabor, Injibara, and Koga) under low and high $\mathrm{N}$ conditions (summarized in Table 3). A total of 52 QTLs were identified for the ten traits distributed over 13 QTL regions on seven of the 12 linkage groups, of which 28 QTLs were detected under low $\mathrm{N}$ while 24 QTLs were detected under high $\mathrm{N}$ conditions. Among the experimental locations, the highest numbers of QTLs under low and high $\mathrm{N}$ conditions together, were detected in Debre-Tabor and Koga (19 QTLs). The identified QTLs accounted for a 11.9 to $37.1 \%$ of the total phenotypic variation for low $\mathrm{N}$, and 15.3 to $38.4 \%$ for high $\mathrm{N}$ conditions.

Many QTLs were detected repeatedly across locations and $\mathrm{N}$ levels (Table 4). We considered QTLs detected in at least two of the three experimental locations under both low $\mathrm{N}$ and high $\mathrm{N}$ conditions to be constitutive and $\mathrm{N}$-level independent QTLs, and QTLs that were exclusively detected in at least two of the three experimental locations under either high $\mathrm{N}$ or low $\mathrm{N}$ conditions as high $\mathrm{N}$-specific or low-N specific QTLs. Four QTLs were low N specific and 4 QTLs were high N specific, suggesting the presence of QTL $x \mathrm{~N}$ interaction. The remaining 3 QTLs were detected under both $\mathrm{N}$ conditions. DTM, NUE and TYPP were some of the traits that had low N specific QTLs, while high N specific QTLs were detected for LCC, Vmax and AUC (Table 3). 
Table 1 Mean performance, Difference due to $\mathrm{N}$ level and difference of parent $\mathrm{C}$ and parent $\mathrm{E}$, and the progeny for some selected traits under low Nitrogen and high Nitrogen conditions

\begin{tabular}{|c|c|c|c|c|c|c|c|c|c|}
\hline \multirow[t]{3}{*}{ Traits } & \multicolumn{3}{|l|}{ Parent C } & \multicolumn{3}{|l|}{ Parent E } & \multicolumn{3}{|l|}{ Progeny } \\
\hline & \multicolumn{2}{|l|}{ Mean } & \multirow{2}{*}{$\begin{array}{l}\text { Reduction }(\%) \text { at Low } \\
\text { nitrogen compared to } \\
\text { high nitrogen }\end{array}$} & \multicolumn{2}{|l|}{ Mean } & \multirow{2}{*}{$\begin{array}{l}\text { Reduction (\%) at Low } \\
\text { nitrogen compared to } \\
\text { high nitrogen }\end{array}$} & \multicolumn{2}{|l|}{ Mean } & \multirow{2}{*}{$\begin{array}{l}\text { Reduction }(\%) \text { Low } \\
\text { nitrogen compared to } \\
\text { high nitrogen }\end{array}$} \\
\hline & $\begin{array}{l}\text { Low } \\
\text { Nitrogen }\end{array}$ & $\begin{array}{l}\text { High } \\
\text { nitrogen }\end{array}$ & & $\begin{array}{l}\text { Low } \\
\text { Nitrogen }\end{array}$ & $\begin{array}{l}\text { High } \\
\text { nitrogen }\end{array}$ & & $\begin{array}{l}\text { Low } \\
\text { Nitrogen }\end{array}$ & $\begin{array}{l}\text { High } \\
\text { nitrogen }\end{array}$ & \\
\hline Plant height(cm) & 31 & 37 & 17 & 36 & 43 & 16.7 & 28 & 35 & 20 \\
\hline $\begin{array}{l}\text { Lower leaf } \\
\text { chlorophyll } \\
\text { content }\end{array}$ & 46 & 49 & 6 & 46 & 49 & 4.8 & 47 & 52 & 10 \\
\hline Days to maturity & 88 & 85 & 2.5 & 87 & 85 & 1.7 & 86 & 84 & 2 \\
\hline $\begin{array}{l}\text { Tuber number } \\
\text { per plant }\end{array}$ & 8 & 13 & 36.9 & 6 & 9 & 38.7 & 7 & 10 & 30 \\
\hline $\begin{array}{l}\text { Average tuber } \\
\text { weight(gram) }\end{array}$ & 35.2 & 35.4 & 0.5 & 28.7 & 34 & 15.7 & 24 & 29 & 17 \\
\hline $\begin{array}{l}\text { Tuber yield per } \\
\text { plant(gram) }\end{array}$ & 300 & 430 & 31.5 & 170 & 320 & 46.4 & 170 & 287 & 41 \\
\hline $\begin{array}{l}\text { Nitrogen use } \\
\text { efficiency }\end{array}$ & 57.8 & 26.6 & 117.3 & 37.76 & 22.85 & 65.3 & 34 & 18 & 89 \\
\hline $\begin{array}{l}\text { maximum } \\
\quad \text { canopy } \\
\text { cover }(\%)\end{array}$ & 40.5 & 50.9 & 20.5 & 31.75 & 46.43 & 31.6 & 27 & 40 & 33 \\
\hline $\begin{array}{l}\text { Area under the } \\
\text { canopy curve } \\
\text { (\%.thermal } \\
\text { day) }\end{array}$ & 1138.23 & 1174 & 3.05 & 750.57 & 1139.4 & 34.13 & 649 & 953 & 32 \\
\hline
\end{tabular}

$\mathrm{PH}=$ Plant height, $\mathrm{LCC}=$ lower leaf chlorophyll content, $\mathrm{DTM}=$ Days to maturity, TNPP $=$ Tuber number per plant, ATW = Average tuber weight, TYPP $=$ Tuber yield per plant, NUE $=$ Nitrogen use efficiency, $\mathrm{Vmax}=$ maximum canopy cover, AUC $=$ Area under the canopy curve

The CxE population is a backcross population with three alleles. Thus, we treated it as a CP population type (population resulting from a cross between heterogeneous, heterozygous and homozygous diploid parents) in the MapQTL model, because all other models in Map QTL assume a maximum of two alleles. Consequently, the genotypes were coded with "ab $\mathrm{x} c \mathrm{c}$ ", where $\mathrm{a}$ and $\mathrm{b}$ represent the alleles of parent $\mathrm{C}$ and $\mathrm{c}$ and $\mathrm{d}$ represent the alleles of parent $\mathrm{E}$ with possible genotypes ac, $\mathrm{ad}, \mathrm{bc}$, and bd. In our backcross population, one of the alleles derived from the $\mathrm{C}$ parent is in fact identical to one of the $\mathrm{E}$ derived alleles, but haplotype information is not available, so it was not possible to distinguish which allele is which. For example, the QTLs identified for days to maturity (DTM) on linkage group IX under low and on linkage group $\mathrm{V}$ under high $\mathrm{N}$ conditions at Debre-Tabor indicate that, the 'c' allele from the E-parent most likely contributes to late maturity type in this population (Fig. 4a and b). The QTL identified on chromosome $\mathrm{V}$ with peak marker SPAD237 for tuber number per plant detected under both $\mathrm{N}$ conditions showed a similar positive contribution of the E parent-derived allele (Fig. 4c and d). For tuber yield per plant, however, a specific combination of C- and E-derived alleles was linked to high tuber yields (Fig. 4e and f) for each of the QTLs.

The identification of similar QTLs for plant height, maximum canopy cover and tuber number per plant with similar allele contributor under both $\mathrm{N}$ conditions suggests that the same gene effect may be responsible for these QTLs. However, the QTLs identified for tuber yield per plant had different allele contributors for low and high $\mathrm{N}$ levels. Overall, as shown in Fig. 4, the CE progeny that had the alleles corresponding to ' $\mathrm{a}$ ' from the female parent $\mathrm{C}$ and allele ' $c$ ' from the male parent $\mathrm{E}$ showed a high score, and allele ' $c$ ' was responsible for the high value in most listed traits under low and high $\mathrm{N}$ conditions.

Of the 13 QTL regions, four genomic regions, i.e. on linkage group $\mathrm{V}$ between 21 and $38 \mathrm{cM}, 38-56 \mathrm{cM}$, and $58-70 \mathrm{cM}$, and on linkage group IV between 60 and $72 \mathrm{cM}$ contained QTL regions accumulating QTLs for more than one trait under different $\mathrm{N}$ conditions and locations. The peak markers for the QTL regions on chromosome V were more than $20 \mathrm{cM}$ apart, which might indicate these are indeed independent QTL regions. However, we do not have sufficient marker information and recombinants to confirm this. The QTLs for AUC, PH, Vmax, DTM, TNPP, TYPP and NUE co-localized between 21 and $38 \mathrm{cM}$ on linkage group V. QTLs for DTM and $\mathrm{PH}$ under both $\mathrm{N}$ conditions, and Vmax, AUC and TYPP under high $\mathrm{N}$ conditions co-located between 38 and $56 \mathrm{cM}$ on linkage group V. This co-localization of QTLs of different traits in the same chromosomal regions suggests the existence of physiological and/or genetic relationships 
Fig. 2 Difference in canopy development process of some CE genotypes selected randomly based on maturity group using raw canopy cover data and maturity data under low $\mathrm{N}$ condition, a) early maturing, b) late maturing
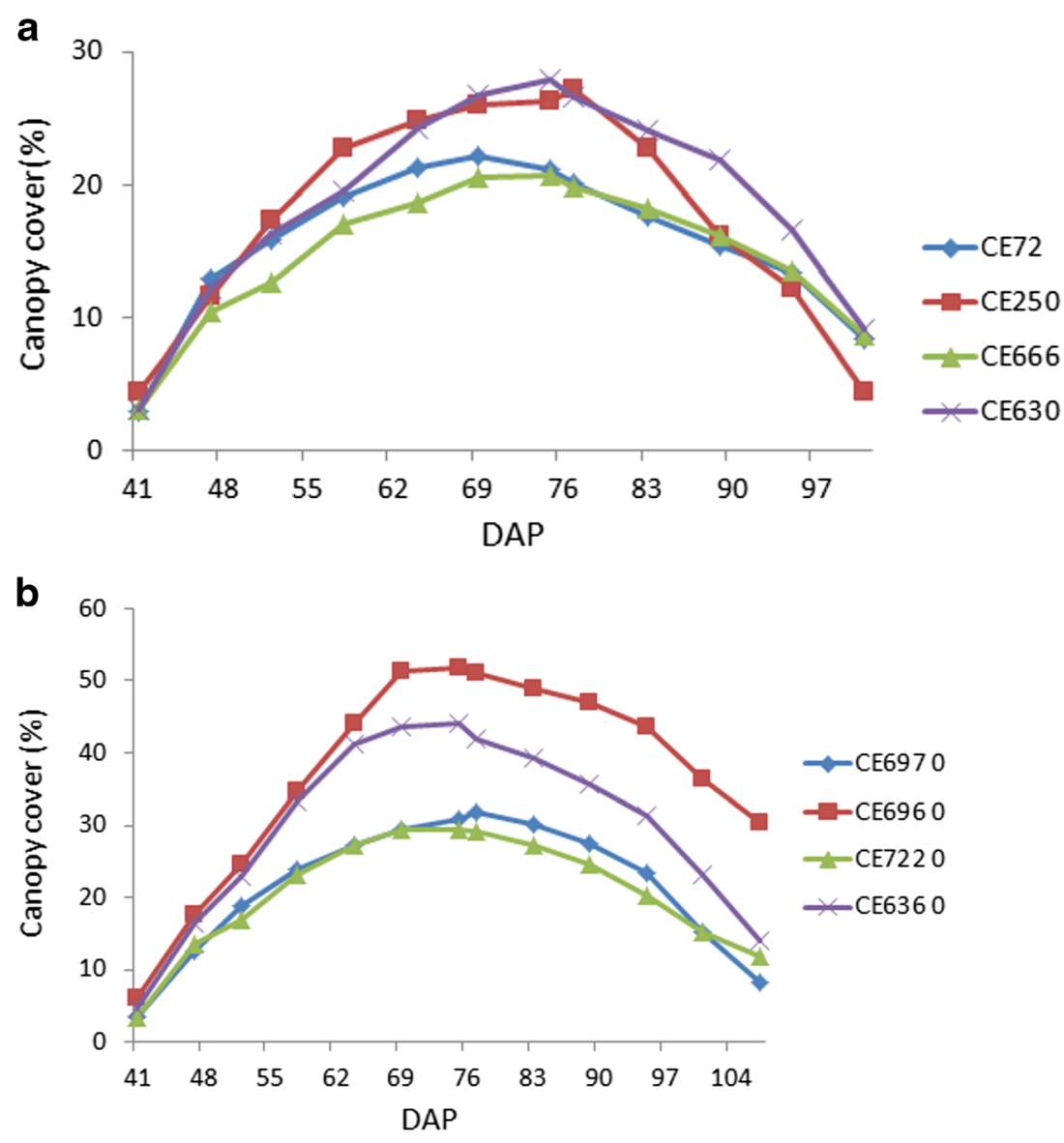

Table 2 Coefficients of correlations (r) between various physiological and agronomic traits, of the mapping population under low $\mathrm{N}$ and high $\mathrm{N}$ conditions

\begin{tabular}{|c|c|c|c|c|c|c|c|c|c|c|c|c|c|c|c|c|c|}
\hline \multicolumn{2}{|c|}{ Treatments } & \multicolumn{16}{|c|}{ High N } \\
\hline & Traits & $\mathrm{PH}$ & SNPP & LCC & UCC & $\mathrm{tm} 1$ & $\mathrm{t} 1$ & $\mathrm{t} 2$ & te & $V \max$ & AUC & DTM & TNPP & TYPP & ATW & TDM $\%$ & NUE \\
\hline \multirow[t]{16}{*}{ Low N } & \multirow{3}{*}{$\begin{array}{l}\text { PH } \\
\text { SNPP } \\
\text { LCC }\end{array}$} & 0.88 & 0.13 & 0.01 & -0.09 & 0.22 & 0.40 & 0.19 & 0.02 & 0.78 & 0.60 & 0.41 & 0.48 & 0.67 & 0.23 & -0.24 & 0.58 \\
\hline & & 0.08 & 0.51 & -0.26 & -0.22 & 0.42 & 0.41 & 0.24 & -0.02 & 0.41 & 0.29 & 0.23 & 0.46 & 0.36 & -0.22 & -0.20 & 0.33 \\
\hline & & -0.02 & -0.08 & 0.68 & 0.83 & -0.05 & -0.10 & -0.25 & -0.17 & -0.16 & -0.19 & 0.00 & -0.18 & -0.23 & -0.06 & 0.17 & -0.15 \\
\hline & $\mathrm{UCC}$ & -0.16 & -0.19 & 0.82 & 0.75 & -0.07 & -0.15 & -0.20 & -0.14 & -0.21 & -0.24 & -0.05 & -0.17 & -0.29 & -0.18 & 0.20 & -0.19 \\
\hline & $\operatorname{tm} 1$ & 0.17 & 0.50 & -0.21 & -0.15 & 0.52 & 0.52 & 0.24 & 0.03 & 0.44 & 0.32 & 0.63 & 0.46 & 0.42 & -0.06 & -0.09 & 0.39 \\
\hline & $\mathrm{t} 1$ & 0.21 & 0.51 & -0.09 & -0.16 & 0.65 & 0.56 & 0.57 & 0.00 & 0.62 & 0.47 & 0.57 & 0.53 & 0.52 & -0.01 & -0.15 & 0.52 \\
\hline & $\mathrm{t} 2$ & -0.06 & 0.46 & -0.12 & -0.12 & 0.47 & 0.38 & 0.21 & 0.24 & 0.31 & 0.34 & 0.37 & 0.39 & 0.38 & -0.05 & -0.12 & 0.39 \\
\hline & te & 0.06 & 0.23 & -0.03 & -0.08 & 0.11 & -0.06 & 0.32 & 0.69 & 0.07 & 0.14 & 0.12 & 0.04 & 0.04 & -0.02 & -0.07 & 0.06 \\
\hline & $V \max$ & 0.65 & 0.22 & -0.12 & -0.30 & 0.26 & 0.35 & 0.01 & 0.03 & 0.77 & 0.73 & 0.55 & 0.69 & 0.82 & 0.14 & -0.31 & 0.74 \\
\hline & AUC & 0.60 & 0.27 & -0.15 & -0.30 & 0.32 & 0.31 & 0.11 & 0.25 & 0.94 & 0.75 & 0.43 & 0.57 & 0.70 & 0.05 & -0.24 & 0.62 \\
\hline & DTM & 0.23 & 0.53 & -0.14 & -0.28 & 0.59 & 0.52 & 0.28 & 0.06 & 0.39 & 0.41 & 0.73 & 0.47 & 0.57 & 0.11 & -0.13 & 0.57 \\
\hline & TNPP & 0.23 & 0.54 & -0.13 & -0.26 & 0.40 & 0.39 & 0.38 & 0.16 & 0.52 & 0.53 & 0.53 & 0.85 & 0.74 & -0.37 & -0.27 & 0.65 \\
\hline & TYPP & 0.55 & 0.44 & -0.22 & -0.36 & 0.39 & 0.38 & 0.24 & 0.17 & 0.73 & 0.73 & 0.57 & 0.66 & 0.87 & 0.27 & -0.30 & 0.87 \\
\hline & ATW & 0.46 & -0.11 & -0.11 & -0.15 & 0.05 & 0.10 & -0.18 & 0.01 & 0.27 & 0.25 & 0.10 & -0.36 & 0.38 & 0.73 & -0.04 & 0.23 \\
\hline & TDM $\%$ & -0.06 & -0.13 & 0.19 & 0.18 & 0.03 & 0.12 & -0.06 & -0.03 & -0.21 & -0.18 & 0.11 & -0.20 & -0.21 & 0.01 & 0.34 & 0.07 \\
\hline & NUE & 0.55 & 0.41 & -0.17 & -0.32 & 0.40 & 0.41 & 0.23 & 0.18 & 0.67 & 0.68 & 0.62 & 0.63 & 0.92 & 0.38 & 0.11 & 0.76 \\
\hline
\end{tabular}

Color Key $\quad-1 \quad 0$

$\mathrm{Ph}=$ Plant Height, SNPP = stem number per plant, LCC $=$ Lower leaves chlorophyll content, $\mathrm{UCC}=$ upper leaf chlorophyll content tm $1=$ inflection point in canopy building phase, $\mathrm{t} 1=$ canopy stabilized, $\mathrm{t} 2=$ on set of canopy decline, te $=$ time canopy cover zero, Vmax $=$ maximum canopy cover in percent, $\mathrm{AUC}=$ total area under the canopy, DTM = days to maturity, TNPP = Tuber Number Per Plant, TYPP $=$ Tuber Yield Per Plant, ATW = Average Tuber Weight, TDM\% = Tuber Dry Matter in percent, NUE = Nitrogen use efficiency 

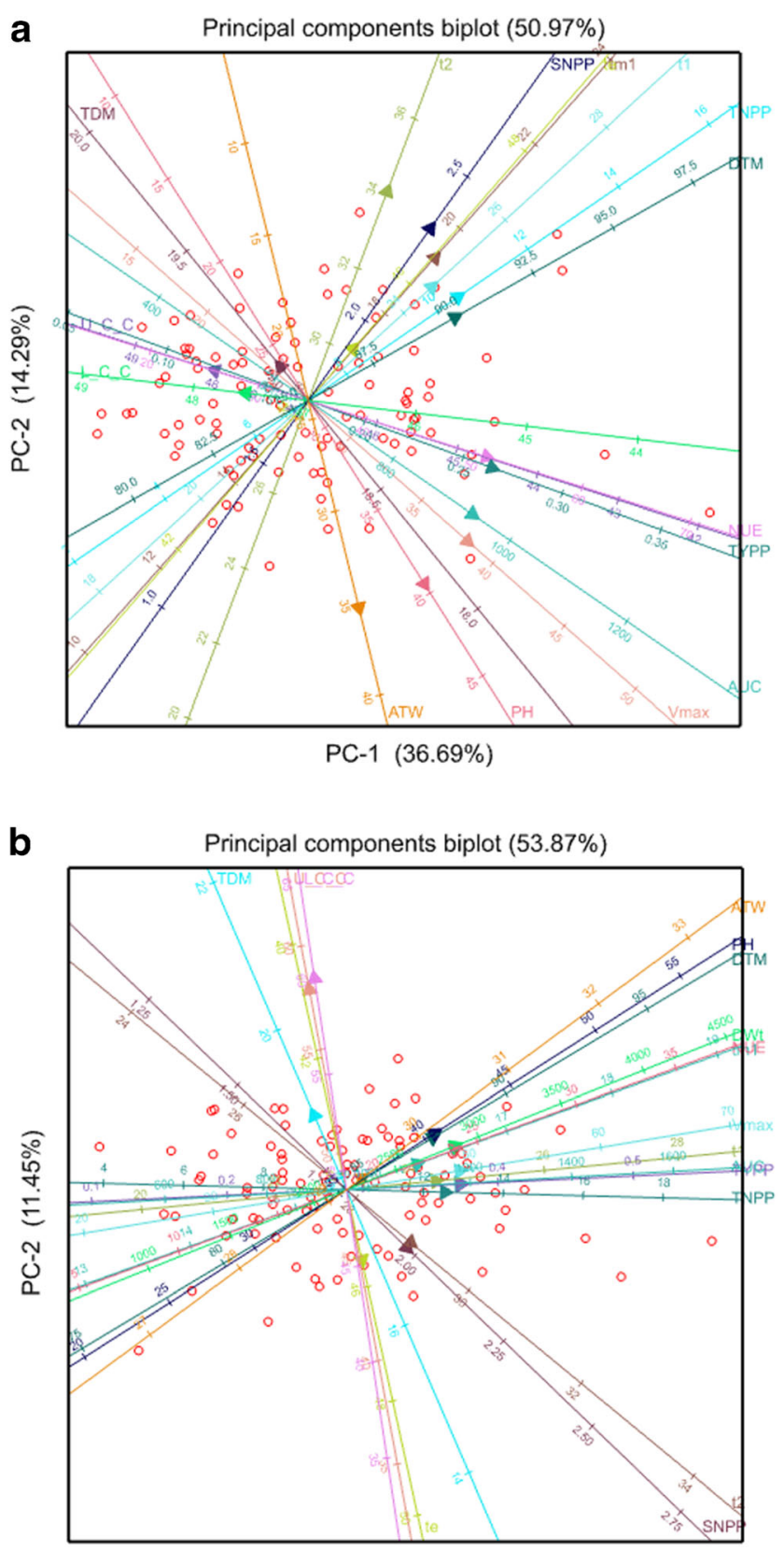

PC-1 $(42.43 \%)$

Fig. 3 a) Bi-plot of $\mathrm{PC} 1$ viz. $\mathrm{PC} 2$ from principal component analysis showing the distribution and similarities among $100 \mathrm{CE}$ potato genotypes under low N, b) Bi-plot of PC1 viz. PC2 from principal component analysis showing distribution and similarities among $100 \mathrm{CE}$ potato genotypes under high $\mathrm{N}$

between these traits. NUE and DTM under low N conditions shared the same QTL region (60-72 cM) on linkage group IV, explaining $23.2 \%$ and $21.7 \%$ of the total phenotypic variation of NUE and DTM respectively. In total, $77 \%$ of the detected QTLs were located on linkage group V, grouped into 4 cluster regions. From these 4 QTL cluster regions, the region between 21 and $38 \mathrm{cM}$ accumulated most QTLs for NUE and related traits. Environments are described in Table 4, QTL names are given as trait name followed by location and the N-levels e.g.
AUC I LN: Area under canopy (AUC); Location, Injibara (I); N-Level (LN), low N.

\section{Discussion}

Breeding for higher yields in crops can be successful via the monitoring and selection for the component physiological traits that determine biomass partitioning and production, and the identification of QTLs that control the heritable variation of these traits (Tuberosa et al. 2008). This is especially true for improving yields under stressful conditions, like low nutrient availability. In the present study, the CxE backcross diploid potato population was evaluated under field conditions to identify QTLs that contribute to NUE and related traits under low and high $\mathrm{N}$ availability in potato.

The pooled analysis of variance showed significant differences between genotypes, locations, $\mathrm{N}$ levels, and their interaction for most measured traits. Nitrogen availability affects various physiological processes and morphological traits of the potato crop. TYPP, TNPP, and Vmax were among the traits that were strongly affected by $\mathrm{N}$ level in our study. Vos and Biemond (1992) reported that $\mathrm{N}$ availability affects the rate of canopy development, leaf appearance, final leaf size and rate of photosynthesis. $\mathrm{N}$ supply was also suggested to affect onset of tuberization, final tuber yield and harvest index (Ewing and Struik 1992; Vos 1995; Vos \& MacKerron2000; Ospina et al. 2014). In our study, area under the canopy curve (AUC) was significantly affected by the level of applied N. Similarly, Grindlay (1997) and Ospina et al. (2014) reported that limitation in N supply affects canopy cover negatively, resulting in reduction in the amount of solar radiation intercepted and the overall photosynthetic capacity.

\section{QTL Identification}

To date, only a few studies report QTLs regulating potato responses to abiotic stress (Anithakumari et al. 2011, 2012; Khan et al. 2014; Ospina 2016). Our study detected multilocation as well as multi-treatment QTLs for NUE and NUE-related traits. Most of the 52 identified QTLs explained more than $15 \%$ of the total phenotypic variation of the trait.

Four genomic regions which harbor QTLs affecting more than one trait were identified on linkage group $\mathrm{V}$ and on linkage group IV under different $\mathrm{N}$ levels and locations. AUC, PH, Vmax, DTM, TNPP, TYPP and NUE QTLs co-localized on linkage group $\mathrm{V}$ between 21 and $38 \mathrm{cM}$ and most of the QTLs had the same peak markers, indicating that a single gene with pleiotropic effects may contribute more to this cluster of traits or that the measured traits are physiologically and/or morphologically linked (El-Soda et al. 2014). These traits had a strong positive correlation with NUE and with each other 
Fig. 4 Expected mean of CE offspring for some selected trait QTLs in different genomic locations which indicates the contribution of each parent for the expected mean of each trait under high $\mathrm{N}$ and low $\mathrm{N}$ condition in Debre-Tabor. allele $a$ and $b$ from female parent; and allele $\mathrm{c}$ and $\mathrm{d}$ from male parent a) QTL code: DTM_D_HN2 for marker E32M51-1c9 on linkage group IX, b) QTL DTM_D_LN2 for marker PotSNP43 on linkage group V, c) QTL code: TNPP_D_ HN for marker SPUD237 on linkage group V, d) QTL code: TNPP D LN for marker SPUD $23 \overline{7}$ on linkage group $\mathrm{V}, \mathrm{e})$ QTL code: TYPP_D_HN for marker PotSNP788 on linkage group VII, f) QTL code: TYPP D_LN for marker SPUD237on linkage group $\mathrm{V}$
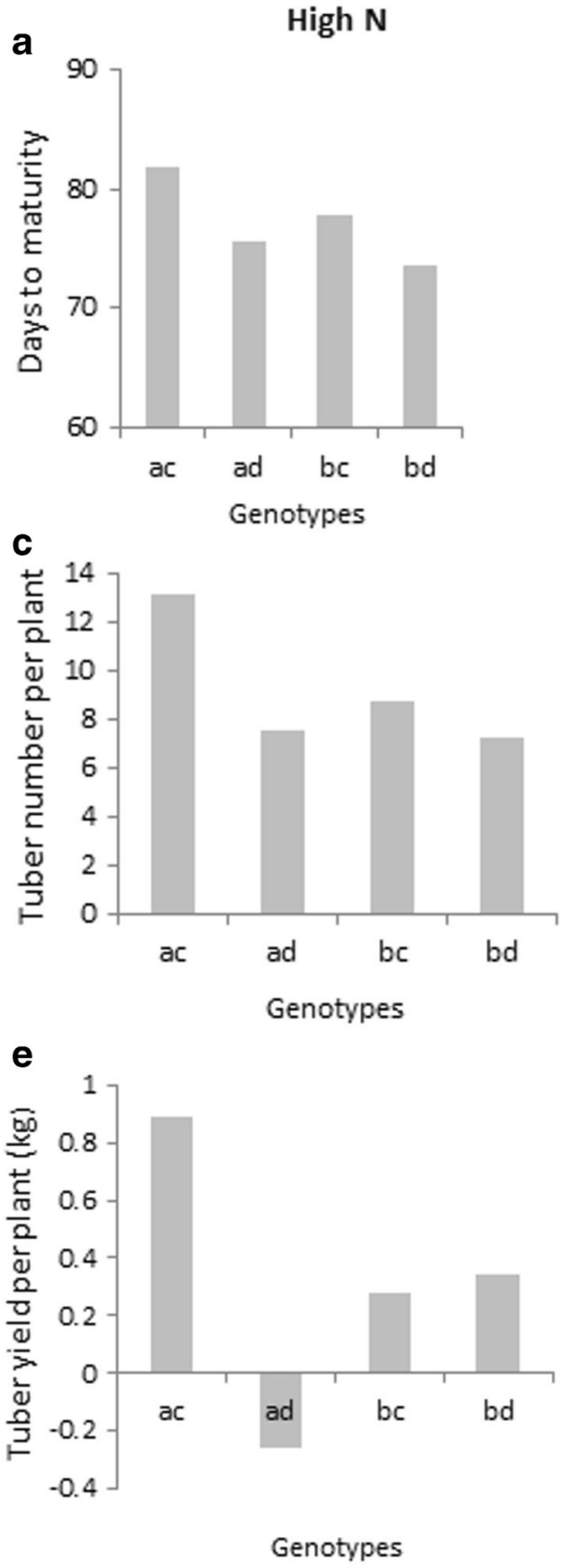

Low N

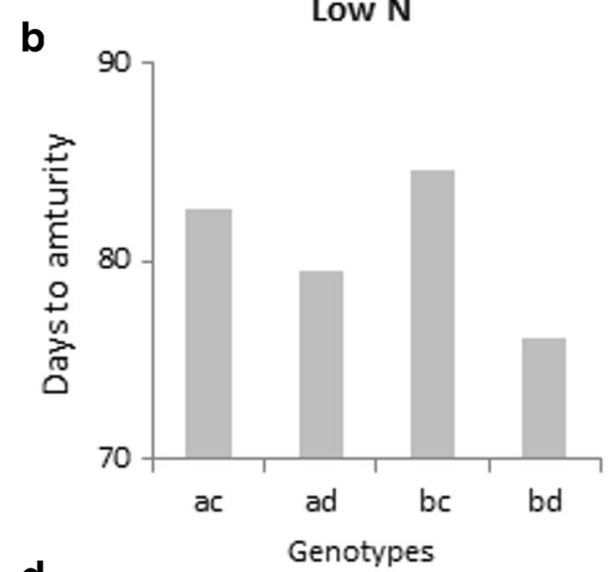

d
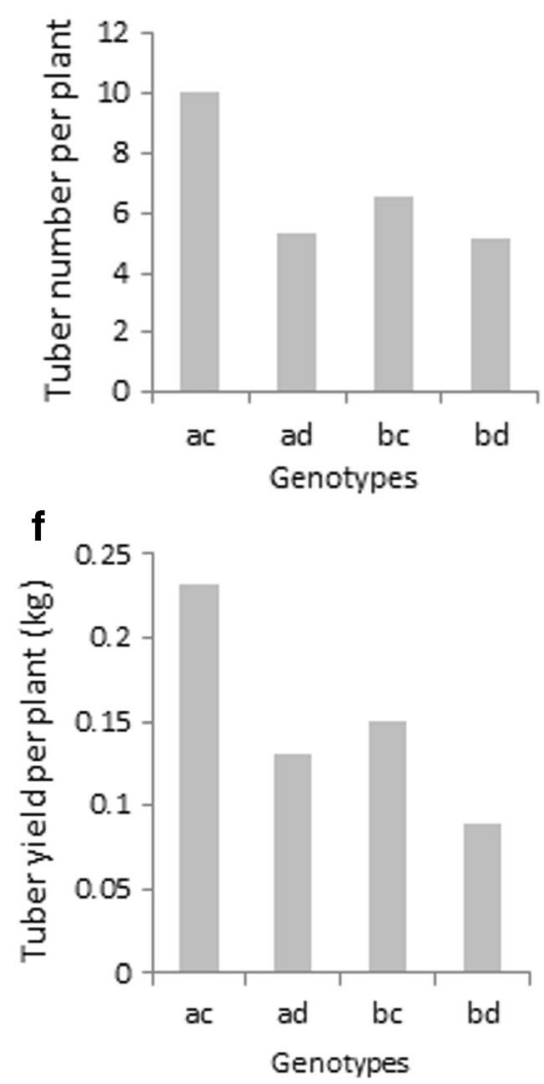

under both $\mathrm{N}$ conditions. The colocalization of yield and canopy traits is in line with Haverkort et al. (1991) and Vos (2009) who reported a strong correlation of canopy cover with intercepted photosynthetically active radiation and tuber yield. The strong positive association of traits with NUE and co-localization in the same QTL region make the traits interesting for breeders to consider them as a selection criterion to improve NUE in the potato breeding programs. This region was found previously to harbour QTLs for multiple traits under different abiotic stresses and normal growing conditions. Anithakumari et al. (2012) in their drought tolerance study found that the same region was associated with shoot fresh weight, tuber number, tuber weight and root length under drought stress and recovery conditions. QTLs associated with foliage maturity and late blight resistance were also identified in this region under normal potato growing conditions (Visker et al. 2005; McCord et al. 2011). Khan et al. (2014) in their drought tolerance study also reported that this QTL region harboured QTLs for plant height, chlorophyll content, tuber number and tuber weight under drought and wellwatered conditions, indicating that the region is a potential QTL region for most important agronomic and physiological traits of potato. This region of linkage group $\mathrm{V}$ in the potato genome is strongly linked to early maturity and initiation of tuberization, for which the CDF1 gene was shown to be responsible 
Table 3 List of agronomic and physiological traits for which QTLs were found in more than one location under low or high $\mathrm{N}$ specific conditions and under both $\mathrm{N}$ level conditions

\begin{tabular}{|c|c|c|c|c|c|c|}
\hline Traits & $\begin{array}{l}\text { High Nitrogen specific } \\
\text { QTLs }\end{array}$ & $\begin{array}{l}\text { Low Nitrogen specific } \\
\text { QTLs }\end{array}$ & $\begin{array}{l}\text { Low and high Nitrogen } \\
\text { conditions }\end{array}$ & $\begin{array}{l}\text { Linkage } \\
\text { group }\end{array}$ & Interval(cM) & Locations \\
\hline Plant height $(\mathrm{cm})$ & & & $\checkmark$ & $\mathrm{V}$ & $21-27$ & $\begin{array}{l}\text { DT and } \\
\text { Injibara }\end{array}$ \\
\hline $\begin{array}{l}\text { lower leaf chlorophyll } \\
\text { content }\end{array}$ & $\checkmark$ & & & II & $46-57$ & DT and Koga \\
\hline $\begin{array}{l}\text { lower leaf chlorophyll } \\
\text { content }\end{array}$ & & $\checkmark$ & & I & $42-48$ & $\begin{array}{l}\text { Koga and } \\
\text { Injibara }\end{array}$ \\
\hline $\begin{array}{l}\text { Area under the canopy } \\
\text { curve }\end{array}$ & $\checkmark$ & & & $\mathrm{V}$ & $24-38$ & $\begin{array}{l}\text { DT and } \\
\text { Injibara }\end{array}$ \\
\hline $\begin{array}{l}\text { Area under the canopy } \\
\text { curve }\end{array}$ & $\checkmark$ & & & $\mathrm{V}$ & $38-50$ & DT and Koga \\
\hline Maximum canopy cover & $\checkmark$ & & & V & $38-49$ & DT and Koga \\
\hline Maximum canopy cover & & & $\checkmark$ & V & $24-38$ & $\begin{array}{l}\text { Koga and } \\
\text { Injibara }\end{array}$ \\
\hline Days to maturity & & $\checkmark$ & & $\mathrm{V}$ & $43-56$ & $\begin{array}{l}\text { DT and } \\
\text { Injibara }\end{array}$ \\
\hline Tuber number per plant & & & $\checkmark$ & $\mathrm{V}$ & $26-38$ & DT and Koga \\
\hline Tuber yield per plant & & $\checkmark$ & & $\mathrm{V}$ & $24-38$ & $\begin{array}{l}\text { DT, IB and } \\
\text { Koga }\end{array}$ \\
\hline Nitrogen use efficiency & & $\checkmark$ & & $\mathrm{V}$ & $24-38$ & DT and Koga \\
\hline
\end{tabular}

$\mathrm{PH}=$ Plant height, $\mathrm{LCC}=$ lower leaf chlorophyll content, $\mathrm{AUC}=$ Area under the canopy curve, $\mathrm{Vmax}=\mathrm{Maximum}$ canopy cover, $\mathrm{DTM}=\mathrm{Days}$ to maturity, TNPP $=$ Tuber number per plant, TYPP $=$ Tuber yield per plant, NUE = Nitrogen use efficiency. DT $=$ Debre-Tabor, IB $=$ Injibara

(Kloosterman et al. 2013). In our study, earliness has a profound influence on NUE regardless of $\mathrm{N}$ level, and our results are in line with the findings of Zebarth et al. (2004) and Ospina et al. (2014). For the most effective use of the QTLs in this region for NUE improvement programs in potato, it may be necessary to see whether the NUE QTL effects are not caused by variation in the CDF1 gene, and to identify the genes that regulate the NUE related traits. If the genes are different from CDF1 gene but linked with it, disentangling the earliness gene from the genes that regulate NUE and other NUE related traits may be helpful or even required to improve these traits.

Additional QTLs for DTM and PH under both N conditions, Vmax, AUC and TYPP under high N conditions, and UCC under low $\mathrm{N}$ condition (in total about 11 QTLs) were co-located in the region ranging from 38 to $56 \mathrm{cM}$ on linkage group V. Previously QTLs associated with foliage traits were also identified in this region: QTLs for fresh biomass (Anithakumari et al. 2011), plant height, shoot fresh weight and shoot dry weight under drought stress and recovery condition (Anithakumari et al. 2012), for fresh and dry harvest index and stem diameter under drought and well-watered condition (Khan et al. 2014) were identified in this region. Most of the QTLs detected in this region are more than $20 \mathrm{cM}$ downstream of the CDF1 gene, and may constitute different loci, independent of the earliness locus. This region may be used as a potential source of genes for NUE improvement.
The QTL region at 58-70 cM on linkage group V harbored 4 QTLs for PH, SNPP and TYPP particularly under low N conditions in Koga. Similarly, Anithakumari et al. (2012) detected QTLs for plant height, stem number, shoot fresh weight and shoot dry weight in this region under drought stress conditions. These QTLs related to growth and yield under both drought stress and $\mathrm{N}$ deficiency conditions are more likely to be independent of maturity, and are potential targets for improving growth under marginal conditions like the test-sites of our trials in Ethiopia.

In addition to the multi-QTL locus on chromosome V, NUE and DTM also shared the same QTL region on linkage group IV under low $\mathrm{N}$ conditions. The strong phenotypic correlation between NUE and DTM and the colocalization of their QTLs at several regions indicates that NUE and DTM are genetically strongly related.

In general, the strong positive correlation of TYPP and NUE with DTM, Vmax, AUC, PH and their coinciding QTLs as reported in this study highlight the genetic and physiological relationship between these traits. Notably, the clustered QTLs had a similar additive effect: Parent E contributed the responsible allele for high performance values for the abovementioned traits under low and high $\mathrm{N}$ conditions. The traits may be causally related and thus could be simultaneously improved in potato breeding. Especially linkage group $\mathrm{V}$ may be enriched with the $\mathrm{N}$ metabolism genes. Coincidence of QTL for traits with QTL effects in the same direction may 
Table 4 QTLs detected for ten agronomic and physiological traits under low and high $\mathrm{N}$ conditions in the CxE mapping population

\begin{tabular}{|c|c|c|c|c|c|c|c|c|}
\hline Traits & Environment & QTL name & $\begin{array}{l}\text { Linkage } \\
\text { Group }\end{array}$ & Peak Marker & LOD & $\begin{array}{l}\text { Peak } \\
\text { position }\end{array}$ & $\begin{array}{l}\text { Interval } \\
(\mathrm{cM})\end{array}$ & $\begin{array}{l}\text { explained. Variation } \\
\text { in } \%\end{array}$ \\
\hline \multirow[t]{5}{*}{ Area under Canopy (AUC) } & IBLN & AUC_I_LN & $\mathrm{V}$ & GP21_2007 & 6.14 & 24.7 & $21-26$ & 26.2 \\
\hline & IBHN & AUC_I_HN & $\mathrm{V}$ & Mando & 6.06 & 26.13 & $24-38$ & 25.9 \\
\hline & $\mathrm{KOHN}$ & $\begin{array}{c}\mathrm{AUC}_{\mathrm{N}} \mathrm{K}_{-} \\
\mathrm{HN} 1\end{array}$ & $\mathrm{~V}$ & Mando & 5 & 26.13 & $24-38$ & 17.5 \\
\hline & DTHN & AUC_D_HN & $\mathrm{V}$ & PotSNP1146 & 5.3 & 43.5 & $38-47$ & 23 \\
\hline & $\mathrm{KOHN}$ & $\begin{array}{c}\mathrm{AUC}_{-} \mathrm{K}_{-} \\
\mathrm{HN} 2\end{array}$ & $\mathrm{~V}$ & PotSNP1143 & 4.5 & 47 & $43-50$ & 20.1 \\
\hline \multirow[t]{7}{*}{ Days to maturity (DTM) } & DTLN & $\begin{array}{l}\text { DTM_D_ }_{-} \\
\text {LN1 }\end{array}$ & IV & PotSNP51 & 4.9 & 65.7 & $60-72$ & 21.7 \\
\hline & IBLN & $\underset{\text { LN1 }}{\text { DTM_I }}$ & $\mathrm{V}$ & Mando & 4.6 & 26.13 & $24-38$ & 14.3 \\
\hline & IBHN & DTM_I_HN & $\mathrm{V}$ & SPUD237 & 5.6 & 31.1 & $26-38$ & 24.1 \\
\hline & IBLN & $\underset{\text { LN2 }}{\text { DTM_I }}$ & $\mathrm{V}$ & PotSNP1143 & 7 & 47 & $43-50$ & 29.2 \\
\hline & DTHN & $\begin{array}{c}\text { DTM_D_ } \\
\text { HN1 }\end{array}$ & V & Myb_t10 & 4.7 & 49.6 & $46-54$ & 16.7 \\
\hline & DTLN & $\underset{\text { LN2 }_{-}}{\text {DTM_D }_{-}}$ & $\mathrm{V}$ & PotSNP43 & 4.8 & 51.6 & $46-56$ & 16.6 \\
\hline & DTHN & $\begin{array}{c}\text { DTM_D }_{-} \\
\text {HN2 }\end{array}$ & IX & E32M51-1c9 & 4.5 & 54.6 & $51-57$ & 15.2 \\
\hline \multirow{6}{*}{$\begin{array}{l}\text { Lower leaf chlorophyll } \\
\text { (LCC) }\end{array}$} & KOLN & LCC_K_LN & I & PotSNP1037 & 4.9 & 44.5 & $42-47$ & 21.4 \\
\hline & DTLN & $\begin{array}{l}\text { LCC_D_ } \\
\text { LN1 } 1\end{array}$ & I & E32M61-18e13 & 5.8 & 45.34 & $42-48$ & 22 \\
\hline & DTLN & $\underset{\mathrm{LN} 2}{\mathrm{LCC} \mathrm{D}_{-}}$ & II & PotSNP1 & 4 & 51.14 & $46-57$ & 15.8 \\
\hline & DTHN & LCC_D_HN & II & PotSNP807 & 5.09 & 51.6 & $46-57$ & 22.3 \\
\hline & KOHN & LCC_K_HN & II & PotSNP807 & 9.4 & 51.6 & $49-57$ & 37.1 \\
\hline & DTLN & $\underset{\mathrm{LN} 3}{\mathrm{LCC} \mathrm{D}_{-}}$ & VIII & E32M51-15 h8 & 5.2 & 81.34 & $77-84$ & 20.1 \\
\hline \multirow[t]{4}{*}{$\begin{array}{l}\text { Nitrogen use efficiency } \\
\text { (NUE) }\end{array}$} & DTLN & $\begin{array}{l}\text { NUE_D_ } \\
\text { LN1 }\end{array}$ & IV & PotSNP51 & 5.34 & 65.7 & $60-72$ & 23.2 \\
\hline & $\mathrm{KOHN}$ & NUE_K_HN & $\mathrm{V}$ & PotSNP573 & 5.5 & 15.5 & $0-21$ & 23.7 \\
\hline & DTLN & $\underset{\text { LN2 }}{\text { NUE_D_- }}$ & V & Mando & 4.9 & 26.13 & $24-38$ & 16.4 \\
\hline & KOLN & NUE_K_LN & $\mathrm{V}$ & SPUD237 & 8.11 & 31.1 & $26-38$ & 33.1 \\
\hline \multirow[t]{8}{*}{ Plant height (PH) } & IBLN & PH_I_LN1 & $\mathrm{V}$ & PBSQ & 5.4 & 24.4 & $21-26$ & 18.7 \\
\hline & IBHN & PH_I_HN1 & $\mathrm{V}$ & GP21_2007 & 6.24 & 24.7 & $21-26$ & 20.5 \\
\hline & KOLN & PH_K_LN1 & $\mathrm{V}$ & GP21_2007 & 7.14 & 24.7 & $21-27$ & 22.5 \\
\hline & KOHN & PH_K_HN1 & $\mathrm{V}$ & GP21_2007 & 5.7 & 24.7 & $24-38$ & 16.6 \\
\hline & IBLN & PH_I_LN2 & $\mathrm{V}$ & Myb_t10 & 4.6 & 49.6 & $46-54$ & 20.4 \\
\hline & IBHN & PH_I_HN2 & $\mathrm{V}$ & Myb_t10 & 5.2 & 49.6 & $46-54$ & 22.8 \\
\hline & KOHN & PH_K_HN2 & $\mathrm{V}$ & E32M61-9 h5 & 5.3 & 61.3 & $58-70$ & 15.3 \\
\hline & KOLN & PH_K_LN2 & $\mathrm{V}$ & E32M61-9 h5 & 6.2 & 61.3 & $58-70$ & 26.5 \\
\hline Stem number/plant (SNPP) & KOLN & $\underset{\text { LN }}{\text { SNPP_K_- }}$ & $\mathrm{V}$ & E32M61-9 h5 & 4.6 & 61.3 & $58-70$ & 20.5 \\
\hline \multirow[t]{5}{*}{ Tuber number/plant (TNPP) } & DTHN & $\begin{array}{c}\text { TNPP_D_ } \\
\text { HN }\end{array}$ & $\mathrm{V}$ & SPUD237 & 5.4 & 31.1 & $26-38$ & 23.3 \\
\hline & DTLN & $\begin{array}{c}\text { TNPP_D } \\
\text { LN }\end{array}$ & $\mathrm{V}$ & SPUD237 & 6.9 & 31.1 & $26-38$ & 28.9 \\
\hline & IBHN & TNPP_I_HN & $\mathrm{V}$ & SPUD237 & 5.8 & 31.1 & $26-38$ & 24.9 \\
\hline & KOHN & $\begin{array}{c}\text { TNPP_K}_{-} \\
\mathrm{HN}\end{array}$ & $\mathrm{V}$ & SPUD237 & 5.3 & 31.1 & $26-38$ & 23.1 \\
\hline & KOLN & $\underset{\text { LN }^{\text {TNPP_K}}}{-}$ & $\mathrm{V}$ & SPUD237 & 6 & 31.1 & $26-38$ & 25.7 \\
\hline Tuber yield/plant (TYPP) & $\mathrm{KOHN}$ & $\begin{array}{c}\text { TYPP_K_ } \\
\mathrm{HN}\end{array}$ & $\mathrm{V}$ & PBSQ & 7.4 & 24.4 & $21-26$ & 30.5 \\
\hline
\end{tabular}


Table 4 (continued)

\begin{tabular}{|c|c|c|c|c|c|c|c|c|}
\hline Traits & Environment & QTL name & $\begin{array}{l}\text { Linkage } \\
\text { Group }\end{array}$ & Peak Marker & LOD & $\begin{array}{l}\text { Peak } \\
\text { position }\end{array}$ & $\begin{array}{l}\text { Interval } \\
(\mathrm{cM})\end{array}$ & $\begin{array}{l}\text { explained. Variation } \\
\text { in } \%\end{array}$ \\
\hline & KOLN & $\underset{\text { LN1 }}{\text { TYPP_K }}$ & $\mathrm{V}$ & Mando & 6.3 & 26.13 & $24-38$ & 21.5 \\
\hline & DTLN & $\begin{array}{l}\text { TYPP_D_ } \\
\text { LN }\end{array}$ & $\mathrm{V}$ & SPUD237 & 8.2 & 31.1 & $26-38$ & 33.2 \\
\hline & IBLN & TYPP_I_LN & $\mathrm{V}$ & SPUD237 & 4.7 & 31.1 & $26-38$ & 20.7 \\
\hline & IBHN & TYPP_I_HN & $\mathrm{V}$ & PotSNP1143 & 5.3 & 47 & $43-50$ & 22.9 \\
\hline & KOLN & $\begin{array}{c}\text { TYPP_K } \\
\text { LN2 }\end{array}$ & $\mathrm{V}$ & E32M61-9 h5 & 4.6 & 61.3 & $58-70$ & 20.2 \\
\hline & DTHN & $\begin{array}{c}\text { TYPP_D_ } \\
\mathrm{HN}^{-}\end{array}$ & VII & PotSNP788 & 7.4 & 42.1 & $39-49$ & 26.6 \\
\hline \multirow[t]{4}{*}{$\begin{array}{l}\text { Upper leaf chlorophyll } \\
\text { (UCC) }\end{array}$} & DTLN & $\begin{array}{l}\mathrm{UCC}_{\mathrm{LN}} \mathrm{D}_{-} \\
\mathrm{LN}\end{array}$ & I & STM5136 & 4.5 & 23 & $18-27$ & 16.5 \\
\hline & DTLN & $\begin{array}{l}\mathrm{UCC}_{-} \mathrm{D}_{-} \\
\mathrm{LN} 2\end{array}$ & II & PotSNP1111 & 4.6 & 112.5 & $106-115$ & 16.7 \\
\hline & DTLN & $\underset{\mathrm{LN} 3}{\mathrm{UCC} \mathrm{D}_{-}}$ & $\mathrm{V}$ & potSNP90 & 6 & 51.6 & $46-56$ & 13.2 \\
\hline & DTLN & $\begin{array}{c}\mathrm{UCC}_{-} \mathrm{D}_{-} \\
\mathrm{LN}\end{array}$ & VII & potSNP542 & 5.5 & 89.2 & $86-91$ & 11.9 \\
\hline \multirow{6}{*}{$\begin{array}{l}\text { Maximum canopy cover } \\
\text { (Vmax) }\end{array}$} & IBLN & Vmax_I_LN & $\mathrm{V}$ & Mando & 5.9 & 26.13 & $24-28$ & 25.2 \\
\hline & IBHN & Vmax_I_HN & V & Mando & 5.4 & 26.13 & $24-38$ & 23.4 \\
\hline & $\mathrm{KOHN}$ & $\underset{\mathrm{HN} 1}{\operatorname{Vmax} \mathrm{K}_{-}}$ & $\mathrm{V}$ & Mando & 4.5 & 26.13 & $24-38$ & 15.8 \\
\hline & KOLN & $\underset{\text { LN }}{\text { Vmax_K }}$ & $\mathrm{V}$ & GP21_2007 & 9.8 & 24.7 & $21-27$ & 38.4 \\
\hline & DTHN & $\begin{array}{c}\text { Vmax_D_ } \\
\mathrm{HN}\end{array}$ & $\mathrm{V}$ & PotSNP1146 & 5.3 & 43.5 & $38-47$ & 23.2 \\
\hline & $\mathrm{KOHN}$ & $\underset{\mathrm{HN} 2}{\mathrm{Vmax} \mathrm{K}_{-}}$ & V & PotSNP1143 & 4.7 & 47 & $43-49$ & 20.9 \\
\hline
\end{tabular}

DTLN = Debre-Tabor low N, DTHN = Debre-Tabor high N, IBLN = Injibara low N, IBHN = Injibara high N, KOLN = Koga low N, KOHN = Koga high $\mathrm{N}$

not provide conclusive evidence, but it offers additional evidence that the two traits are functionally associated (Thumma et.al. 2001). The ultimate evidence that two correlated traits are causally correlated may require identification of the putative candidate genes underlying the traits.

\section{QTL x Environment Interaction}

Quantitative traits are influenced by the environment and have a tendency to express variable degrees of Genotype $\times$ Environment Interaction (GEI). The analysis of variance in this study indicated presence of GEI. However, the $\mathrm{G} \times \mathrm{N}$ level interaction was low as compared $\mathrm{G} x$ location interaction. Gallais and Coque (2005) in their maize NUE genetic variation study reported that although the genotype by $\mathrm{N}$ level interaction was low, different traits and genes may underlie the genetic variation in NUE at high $\mathrm{N}$ and low $\mathrm{N}$ level; the variation at high $\mathrm{N}$ was mainly due to variation in $\mathrm{N}$ uptake while at low $\mathrm{N}$ level both components of NUE had a significant contribution to the total NUE variation. This implies that the genes that control NUE at low $\mathrm{N}$ may be different from those at high $\mathrm{N}$ conditions. This may be reflected in QTL $\mathrm{x}$
Environment interaction (QEI). GEI is determined by all the trait-underlying genes of all QTLs combined, while QEI indicates the interaction of a single QTL with the environment. The presence of highly significant GEI typically may or may not indicate the presence of QEI (Wei et al. 2012). Most of the identified QTLs were present only under low $\mathrm{N}$ or high $\mathrm{N}$ conditions, and only some of them under both $\mathrm{N}$ conditions, at least over two experimental locations. QTLs identified at either low $\mathrm{N}$ or high $\mathrm{N}$ condition are $\mathrm{N}$ level dependent, adaptive QTLs, while QTLs identified under both N condition are $\mathrm{N}$ level independent, constitutive QTLs. The occurrence of adaptive QTLs specific for $\mathrm{N}$ level suggests the presence of QTL $x$ N interaction. Our study was conducted in three different locations, and two production seasons (rainfed and irrigation production) which are different in several environmental factors (altitude, temperature, soil type and water availability) under low and high $\mathrm{N}$ conditions. This difference in environmental factors will have contributed to QEI. However, the QTLs identified for TNPP, TYPP, NUE, Vmax, and AUC were shared in both rain-fed and irrigation production seasons, suggesting that these QTLs are not production season specific. The difference in number of QTLs between locations was 
almost similar to the difference in number of QTL between $\mathrm{N}$ levels, indicating QTL $\mathrm{x}$ location and QTL $\mathrm{x} \mathrm{N}$ level interaction had similar contribution to the total QEI.

\section{Implications for Breeding}

In our study, most measured physiological and agronomic traits had a strong correlation with NUE and co-localized in the same QTL regions. This coincidence of QTLs for NUE with other NUE related traits would suggest the NUE related traits played a role in the NUE performance of potato genotypes (have a causal relationship with NUE). However, to have evidence for causal relationship, identification of the genes that regulate the expression of these correlated traits should be considered in the future study. Moreover, the result suggested that when we simultaneously improve NUE and NUE related traits undesirable genetic linkage and pleiotropy should be considered in the future breeding. Fine mapping and identification of candidate genes is also required to obtain more information about the above mentioned QTL regions simultaneously controlling NUE and related traits. This study can be considered as a first exploratory work on the genetic relation of NUE and related traits under low and high $\mathrm{N}$ condition in potato. Most of the QTLs identified in this study were different across environments, suggesting the use of these QTLs would be difficult in breeding. As a result, to verify whether the identified QTLs in this study are stably expressed in different environments and of use in breeding for general stability, multiple field trials will be required to be conducted in different environments.

Open Access This article is licensed under a Creative Commons Attribution 4.0 International License, which permits use, sharing, adaptation, distribution and reproduction in any medium or format, as long as you give appropriate credit to the original author(s) and the source, provide a link to the Creative Commons licence, and indicate if changes were made. The images or other third party material in this article are included in the article's Creative Commons licence, unless indicated otherwise in a credit line to the material. If material is not included in the article's Creative Commons licence and your intended use is not permitted by statutory regulation or exceeds the permitted use, you will need to obtain permission directly from the copyright holder. To view a copy of this licence, visit http://creativecommons.org/licenses/by/4.0/.

\section{References}

Agrama, H.A.S., A.G. Zacharia, F.B. Said, and M. Tuinstra. 1999. Identification of quantitative trait loci, for nitrogen use efficiency in maize. Molecular Breeding 5: 187-195. https://doi.org/10.1023/ a: 1009669507144 .

Anithakumari, A.M., O. Dolstra, B. Vosman, R.G.F. Visser, and C. Gerard van der Linden. 2011. In vitro screening and QTL analysis for drought tolerance in diploid potato. Euphytica 181: 357-369. https://doi.org/10.1007/s10681-011-0446-6.

Anithakumari, A.M., N. Karaba, K.N. Nataraja, R.G.F. Visser, and C. Gerard van der Linden. 2012. Genetic dissection of drought tolerance and recovery potential by quantitative trait locus mapping of a diploid potato population. Molecular Breeding 30: 1413-1429. https://doi.org/10.1007/s11032-012-9728-5.

Bonierbale, M.W., R.L. Plaisted, and S.D. Tanksley. 1988. RFLP maps based on a common set of clones, reveal modes of chromosomal evolution in potato and tomato. Genetics 120: 1095-1103.

Bradshaw, J., C. Hackett, B. Pande, R. Waugh, and G. Bryan. 2008. QTL mapping of yield, agronomic and quality traits in tetraploid potato (Solanum tuberosum subsp. tuberosum). Theoretical and Applied Genetics 116: 193-211.

Bulmer, M.G. 1985. The mathematical theory of quantitative genetics. Oxford: Clarendon.

Cho, Y., W.Z. Jiang, J.H. Chin, Z.P. Piao, Y.G. Cho, S.R. McCouch, and H.J. Koh. 2007. Identified QTLs associated with physiological nitrogen use efficiency in rice. Molecular Cells 23: 72-79.

Doerge, R.W. 2002. Mapping and analysis of quantitative trait loci in experimental population. Macmillan Magazines Ltd, Nature reviews/Genetics 3: 43-51. https://doi.org/10.1038/nrg703.

El-Soda, M., P. Martin, M.P. Boer, H. Bagheri, C.J. Hanhart, M. Koornneef, and M.G.M. Arts. 2014. Genotype-environment interactions affecting pre-flowering physiological and morphological traits of Brassica rapa grown in two watering regimes. Journal of Experimental Botany 65: 697-708. https://doi.org/10.1093/jxb/ ert434.

Errebhi, M., C.J. Rosen, F.I. Lauer, M.W. Martin, J.B. Bamberg, and D.E. Birog. 1998. Screening of exotic potato germplasm for nitrogen up take and biomass production. American Journal of Potato Research 75: 93-100. https://doi.org/10.1007/BF02883883.

Errebhi, M., C.J. Rosen, F.I. Lauer, M.W. Martin, and J.B. Bamberg. 1999. Evaluation of tuber bearing solanium species for nitrogen use efficiency and biomass partitioning. American Journal of Potato Research 76: 143-151. https://doi.org/10.1007/ BF02853579.

Ewing, E.E., and P.C. Struik. 1992. Tuber formation in potato: Induction, initiation and growth. Horticultural Reviews 14: 89-198.

Falconer, D.S., and T.F.C. Mackay 1996. Introduction to quantitative genetics (Addison- Wesley-Longman, Harlow.

Gallais, A., and M. Coque. 2005. Genetic variation and selection for nitrogen use efficiency in maize: A synthesis. Maydica 50 (3): 531-547.

Gebhardt, C., E. Ritter, T. Debener, U. Schachtschabel, B. Walkemeier, H. Uhrig, and F. Salamini. 1989. RFLP analysis and linkage mapping in Solanum tuberosum. Theoretical and Applied Genetics 78: $65-75$.

Glass, A.D.M. 2003. Nitrogen use efficiency of crop plants: Physiological constraints upon nitrogen absorption. Critical Reviews in Plant Sciences 22 (5): 453-470.

Good, A.G., A.K. Shrawat, and D.G. Muench. 2004. Can less yield more? Is reducing nutrient input into the environment compatible with maintaining crop production? Trends in Plant Science 9 (12): 597-605. https://doi.org/10.1016/j.tplants.2004.10.008.

Grindlay, D. J. 1997. Towards an explanation of crop nitrogen demand based on the optimisation of leaf nitrogen per unit leaf area. J.a.S. 128: 377-396.

Hanneman, R., and S. Peloquin. 1967. Cross- ability of 24-chromosome potato hybrids with 48-chromosome cultivars. Potato Research 10 (1): 62-73.

Haverkort, A.J., D. Uenk, H. Veroude, and M. Van de Waart. 1991. Relationships between ground cover, intercepted solar radiation, leaf area index and infrared reflectance of potato crops. Potato Research 34 (1): 113-121. 
Hawkes, J.G. 1990. The potato: Evolution, biodiversity and genetic resources, 235. London: Belhaven Press.

Hirel, B., and P.J. Lea. 2001. Ammonia assimilation. In plant Nitrogen, ed. P.J. Lea and J.F. Morot-Gaudry, 79-99. Berlin: Springer-Verlag.

Hirel, B., T. Tétu, P.J. Lea, and F. Frédéric Dubois. 2011. Improving nitrogen use efficiency in crops for sustainable agriculture. Sustainability 3: 1452-1485. https://doi.org/10.3390/su3091452.

Jacobsen, E. 1980. Increase of diploid formation and seed set in 4x X 2xcrosses in potatoes by genetical manipulation of dihaploids and some theoretical consequences. Zeitschrift für Pflanzenzüchtung 85 (2): $110-121$.

Khan, M.S. 2012. Assessing genetic variation in growth and development of potato. $\mathrm{PhD}$ thesis Wageningen University, Wageningen.

Khan, M.S., H.J. Van Eck, and P.C. Struik. 2013. Model-based evaluation of maturity type of potato using a diverse set of standard cultivars and a segregating diploid population. Potato Research 56 (2): 127 146

Khan, M.A., D. Saravia, S. Munive, F. Lozano, E. Farfan, R. Eyzaguirre, and M. Bonierbale. 2014. Multiple QTLs linked to agromorphological and physiological traits related to drought tolerance in potato. Plant Molecular Biology Reporter 33: 1286-1298. https:// doi.org/10.1007/s11105-014-0824-z.

Kleinkopf, G.E., D.T. Westermann, M.J. Wille, and G.D. Kleinschmidt. 1987. Specific gravity of russet Burbank potatoes. American Potato Journal 64: 579-587.

Kloosterman, B., J.A. Abelenda, M.D.C. Gomez, M. Oortwijn, J.M. de Boer, and K. Kowitwanich. 2013. Naturally occurring allele diversity allows potato cultivation in northern latitudes. Nature 495: 246250. https://doi.org/10.1038/nature11912.

Lebreton, C., V. Lazic-Jancic, A. Steed, S. Pekic, and S.A. Quarrie. 1995. Identification of QTL for drought responses in maize and their use in testing causal relationships between traits. Journal of Experimental Botany 46 (288): 853-865.

Loudet, O., S. Chaillou, P. Merigout, J. Talbotec, and F. Daniel-Vedele. 2003. Quantitative trait loci analysis of nitrogen use efficiency in Arabidopsis. Plant Physiology 131: 345-358. https://doi.org/10. 1104/pp.102.010785.

McCord, P.H., B.R. Sosinski, K.G. Haynes, M.E. Clough, and G.C. Yencho. 2011. Linkage mapping and QTL analysis of agronomic traits in tetraploid potato (Solanum tuberosum subsp tuberosum). Crop Science 51: 771-785. https://doi.org/10.2135/cropsci2010. 02.0108 .

Miralles, D.J., and G.A. Slafer. 2007. Sink limitations to yield in wheat: How could it be reduced? The Journal of Agricultural Science 145: 139-149.

Moll, R.H., E.J. Kamprath, and W.A. Jackson. 1982. Analysis and interpretation of factors which contribute to efficiency of nitrogen utilization. Agronomy Journal 74: 562-564.

Munoz, F., R.S. Mylavarapu, and C.M. Hutchinson. 2005. Environmentally responsible potato production systems. Journal Plant Nutrition 28: 1287-1309.

Murphy, H.J., and M.J. Goven. 1959. Nitrogen, spuds and specific gravity. Maine Farm Res. 7 (1): 21-24.

Ojala, J.C., J.C. Stark, and G.E. Kleinkopf. 1990. Influence of irrigation and nitrogen management on potato yield and quality. American Journal of Potato Research 67: 29-43.

Olsen, N., G.E. Kleinkopf, and J.C. Stark. 2003. Physiological disorders. In stark JC, ed. S.L. Loves, 309-327. Moscow: Potato production systems. University of Idaho Extension.

Ospina, C.A. 2016. Nitrogen use efficiency in potato: an integrated agronomic, physiological and genetic approach. $\mathrm{PhD}$ thesis Wageningen University, Wageningen.

Ospina, C.A., E.T. Lammerts van Bueren, J.J.H.M. Allefs, B. Engel, P.E.L. van der Putten, C.G. van der Linden, and P.C. Struik. 2014. Diversity of crop development traits and nitrogen use efficiency among potato cultivars grown under contrasting nitrogen regimes. Euphytica 199: 13-29. https://doi.org/10.1007/s10681-014-1203-4.

Pack, J.E., C.M. Hutchinson, and E.H. Simonne. 2006. Evaluation of controlled release fertilizers for Northeast Florida chip potato production. Journal of Plant Nutrition 29: 1301-1313.

Pelleschi, S., A. Leonardi, J.P. Rocher, G. Cornic, D. de Vienne, C. Thevenot, and J.L. Prioul. 2006. Analysis of relationships between growth, photosynthesis and carbohydrate methabolism using quantitative trait loci (QTL) in young maize plants subjected to water deprivation. Molecular Breeding 17: 21-39.

Quarrie, S.A. 1996. New molecular tools to improve the efficiency of breeding for increased drought resistance. Plant Growth Regulation 20 (2): 167-178. https://doi.org/10.1007/BF00024013.

Schafer-Pregl, R., E. Ritter, L. Concilio, J. Hesselbach, L. Lovatti, B. Walkemeier, H.F. Thelen, F. Salamini, and C. Gebhardt. 1998. Analysis of quantitative trait loci (QTLs) and quantitative trait alleles (QTAs)for potato tuber yield and starch content. Theoretical and Applied Genetics 97: 834-846.

Sharifi M, B.J. Zebarth, W. Coleman. 2007. Screening for potato nitrogen use efficiency using a recirculating hydroponic system., in Zhu Z, Minasi K, and Xing G. (eds.) Proceedings of the 3rd international nitrogen conference contributed papers, October 12-16, 2004, Nanjing, China, Science Press, Monmouth Junction, NJ, USA, pp 285-290.

Simko, I., S. McMurry, H.M. Yang, A. Manschot, P.J. Davies, and E.E. Ewing. 1997. Evidence from polygene mapping for a causal relationship between potato tuber dormancy and abscisic acid content. Plant Physiology 115 (1453-1): 459.

Stark, J.C., D.T. Westermann , and B.G. Hopkins. 2004. Nutrient management guidelines for russet Burbank potatoes. Bull. 840. Univ. of Idaho, Moscow.

Thumma, B.R., B.P. Naidu, A. Chandra, D.F. Cameron, L.M. Bahnisch, and C. Liu. 2001. Identification of causal relationships among traits related to drought resistance in Stylosanthes Scabra using QTL analysis. Journal of Experimental Botany 52: 203-214.

Tiemens-Hulscher, M., L.T. Lammerts van Bueren, and R.C.B. Hutten. 2012. Potato: Improving organic cultivars including a participatory approach. In Organic crop breeding, ed. E.T. Lammerts van Bueren and J.R. Myers, 227-223. Hoboken: Wiley-Blackwell.

Tuberosa, R., N.C. Collins, and F. Tardieu. 2008. Quantitative trait loci and crop performance under abiotic stress: Where do we stand? Plant Physiology 147: 469-486.

Van den Berg, J., E. Ewing, R. Plaisted, S. McMurry, and M. Bonierbale. 1996. QTL analysis of potato tuber. Theoretical and Applied Genetics 93: 317-324.

Van Eck, H.J., J.M.E. Jacobs, P. Stam, J. Ton, W.J. Stiekema, and E. Jacobsen. 1994. Multiple alleles for tuber shape in diploid potato detected by qualitative and quantitative genetic analysis using RFLPs. Genetics 137: 303-309.

Van Ooijen, J.W. 2006. Join map 4.0, software for the calculation of genetic linkage maps in experimental populations of diploid species. Plant research international, Wageningen, Netherlands.

Van Ooijen, J.W. 2009. Map QTL 6.0, software for the mapping of quantitative trait loci in experimental populations of diploid species. Kyazma B.V, Wageningen, Netherlands.

Visker, M.H.P.W., H.J.B. Heilersig, L.P. Kodde, W.E. Van de Weg, R.E. Voorrips, P.C. Struik, and L.T. Colon. 2005. Genetic linkage of QTLs for late blight resistance and foliage maturity type in six related potato progenies. Euphytica 143: 189-199. https://doi.org/10. 1007/s10681-005-3444-8.

Vos, J. 1995. The effects of nitrogen supply and stem density on leaf attributes and stem branchingin potato (Solanum tuberosum L.). Potato Research 38: 271-279.

Vos, J. 2009. Nitrogen responses and nitrogen management in potato. Potato Research 52 (4): 305-317. 
Vos, J., and H. Biemond. 1992. Effects of nitrogen on the development and growth of the potato plant. 1. Leaf appearance, expansion growth, life span of leaves and stem branching. Annals of Botany 70: 27-35.

Vos, J., and D.K.L. Mackerron. 2000. Basic concepts of the management and supply of nitrogen and water in potato production. In Management of nitrogen and water in potato production, ed. A.J. Haverkort and Mackerron DKL, 15-33. Wageningen.

Wei, D., K. Cui, G. Ye, J. Pan, J. Xiang, J. Huang, and L. Nie. 2012. QTL mapping for nitrogen- use efficiency and nitrogen deficiency tolerance traits in rice. Plant Soil 359: 281-295. https://doi.org/10.1007/ s11104-012-1142-6.

Welcker, C., B. Boussuge, C. Benciveni, J.M. Ribaut, and F. Tardieu. 2007. Are source and sink strengths genetically linked in maize plants subjected to water deficit? A QTL study of the responses of leaf growth and anthesis- silking interval to water deficit. Journal of Experimental Botany 58: 339-349.
Yin, X., J. Goudriaan, E.A. Lantinga, J. Vos, and H.J. Spiertz. 2003. A flexible sigmoid function of determinate growth. Annals of Botany 91 (3): 361-371.

Zebarth, B.J., G. Tai, R. Tarn, H. de Jong, and P.H. Milburn. 2004. Nitrogen use efficiency characteristics of commercial potato cultivars. Canadian Journal of Plant Science 84: 589-598.

Zhang, F., Z. Cui, J. Wang, C. Li, and X. Chen. 2007. Current status of soil and plant nutrient management in China and improvement strategies. Chinese Bull. Bot. 24 (6): 687-694.

Zheng, Z.L. 2009. Carbon and nitrogen nutrient balance signalling in plants. Plant Signal Behavior 4: 584-591. https://doi.org/10.4161/ psb.4.7.8540.

Zvomuya, F., C.J. Rosen, and J.C. Miller. 2002. Response of russet Norkotah clonal selection to nitrogen fertilization. American Journal of Potato Research 79: 231-239. https://doi.org/10.1007/ BF02986355. 